\title{
You Must Know Your Faith in Detail: Redefinition of the Role of Knowledge and Boundaries of Belief in Ottoman Catechisms ('ilm-i hậls)
}

\author{
Tijana Krstić
}

Although still far from providing a comprehensive picture, recent research on Islamic theology in post-fourteenth-century Central Asia as well as the Ottoman and Safavid realms has challenged the long-established view that in the "postclassical" era, and especially in these regions, the works on kaläm became repetitive and derivative at best, or that the discipline experienced a complete demise, at worst. ${ }^{1}$ This view has long obfuscated new directions and tendencies in later kalām, often articulated in neglected glosses, commentaries, and supercommentaries on the works of older masters, which offer plentiful evidence of what Khaled El-Rouayheb has identified as new "textualphilological methodologies" through which scholars engaged with past works and arguments, not with the purpose of blindly imitating (taqlid) but elaborating and/or independently verifying them (tahqüq). ${ }^{2}$ Reflecting on recent efflorescence in research on early modern Islamic intellectual history, Matthew Melvin-Khoushki observed that unlike their European contemporaries who famously insisted on going back to and emulating the ancients, Ottoman scholars were perfectly content to textually inherit ancient learning through the "well-burnished prism" of their immediate Timurid, Turkmen, and Mamluk scholarly predecessors. Nevertheless, both Islamic and European scholars engaged in translating, commenting on, refining, critiquing, rejecting, subverting, and editing their intellectual patrimony_-practices that Melvin-Khoushki groups under the broad rubric of tahqīq, or verification through independent reasoning - which, he suggests, constituted "a new epistemic style that is distinctively early modern." 3

1 For a critical overview of this stance as well as decline narratives that converged on the Ottoman period, see El-Rouayheb, Islamic intellectual history 173-174, 102. Other critical studies include Spannaus, Theology in Central Asia; Özervarl, Theology in the Ottoman lands; essays in Demir et al. (eds.), Osmanlida ilm-i kelâm; Badeen, Sunnitische Theologie; Yazıcıŏglu, Le kalâm, etc.

2 El-Rouayheb, Islamic intellectual history $97-128$. On commentaries and supercommentaries, see ibid. 33; Ahmed, Post-classical; Saleh, The gloss as intellectual history.

3 Melvin-Khoushki, Tahquīq vs. taqlïd 214 and 216.

(C) TIJANA KRSTIĆ, 2021 | DOI:10.1163/9789004440296_006

This is an open access chapter distributed under the terms of the CC BY-NC-ND 4.o licenseå Krstić - 9789004440296 
The concept of tahqiq -although in a different sense-was also central to the theological debates that reached back to the early days of the Muslim community, on faith (immann) and the necessary knowledge of Islam that qualifies one for being considered a believer $\left(\mathrm{mu}^{\prime} \mathrm{min}\right)$, as well as the degree of the obligation to "know." In this context, particularly contentious was the question of whether faith could essentially be reducible to knowledge and whether the kind of knowledge that would allow one to verify the truthfulness of one's faith must be based on reasoning (nazar) and inference (istidläl). The eponymous founders of the two Sunni theological schools, Abū Manșūr al-Māturīdī (d. 333/944) and Abū al-Ḥasan al-Ash'arī (d. 324/935-936), along with their Mu'tazilite opponents, leaned toward the affirmative answer and questioned the validity of faith based on the authority of others (taqlid) that lacked any understanding of the underlying proofs for the articles of faith. This view, however, threatened the status as a believer of the majority of common Muslims and came to be known as al-qawl bi-kufr al-ämma (i.e., the thesis that condemns the common people as unbelievers), generating much debate among the theologians. The contentiousness of the question made sure that the issue of imitative faith (al-imān bi-l-taqlid ), as well as the accompanying problem of how much knowledge and what kind of knowledge was required in order for one to be considered a believer, came to be a staple topic in creeds ('aqā'id) and manuals on principles of Islam (ușül al-dìn) since the fourth/tenth century.

Building on recent studies on postclassical kaläm as well as the research on rearticulations of Sunni orthodoxy in the early modern Ottoman Empire, the present paper seeks to address the issue of tahqiq both in a general sense, as an Islamic mode of engagement with the intellectual patrimony, and in a specific sense relevant to the theological discussions of the relationship between faith and knowledge in creedal texts, with emphasis on the tenth/sixteenth and eleventh/seventeenth centuries. To that end, the paper will explore how Ottoman Rumi authors (i.e. from the Balkans and Anatolia) who wrote catechetical works (Tr. ilm-i hă $l$ ) for common Muslims in Turkish engaged with the earlier theological works to discuss the question of imitative faith (Tr. imān-i takli $\bar{d} \bar{\imath})$ as well as the corollary problem of whether it is sufficient to assent (tass$d \bar{i} q$ ) to faith in general terms or in detail, and consequently, whether one's faith should be of summary (Tr. ìmān-i icmālì) or detailed kind (Tr. immān-i tafșìlì). In order to shed light on the evolution of the debate, the first part of the paper will examine the Maturidi, Ash'ari, and to a lesser extent Mu'tazili theologians'

4 For a background on these debates, see Izutsu, The concept, esp. 57-129; Frank, Knowledge and taqlîd. 
views that informed later Ottoman authors, whose approaches to the issue will constitute the mainstay of the subsequent discussion. In the final part, the paper will turn to the question of why kaläm continued to be socially relevant in a polity such as the Ottoman Empire, contextualizing this question with reference to the discussions on "Sunnitization" and confessional polarization in the tenth/sixteenth and eleventh/seventeenth centuries.

\section{The Relationship between Faith and Knowledge as Understood by Ash'arites and Maturidites before the Ninth/Fifteenth Century}

The discussions about the kind and degree of knowledge about imann that one had to have both in order to be considered a Muslim and in order to qualify as a believer and be guaranteed salvation on the Day of Judgment were triggered by the specific historical circumstances that the growing Muslim community faced in the first two centuries, namely how to set the boundaries of membership in the umma in the face of the growing conversions to Islam. For the evolution of the Maturidi school of theology and the position of the Maturidi scholars on the issue, the decisive developments took place in second/eighthcentury Transoxania, which was conquered by the Muslims in the beginning of the century and where conversions of the local populations were on the rise. The ensuing question of whether or not converts should be paying poll tax triggered a theological debate on what kind of knowledge one should have in order to be counted as a Muslim. ${ }^{5}$ This prompted the Murji'a—a group that had come to define faith exclusively as a declaration by tongue and argued that deeds (such as performance of the rites of worship) had no impact on one's faithwho dominated the political scene in Transoxania, to reach out to the scholars in Kufa, in Iraq, which was the traditional stronghold of the Murji'a. Here they found support from one of the city's most prestigious scholars at the time, Abu Hanifa (d. 150/767), who himself was sympathetic to their views. This had a lasting impact on Eastern Iran, whose Muslim population overwhelmingly embraced Abū Hanīfa's teachings by the early ninth century. ${ }^{6}$ Although Abū Hanifa is today remembered as the founder of one of the four Sunni schools of law (madhhab), none of his writings on law ( figh) actually survive, while the texts that can with some certainty be attributed to him or to the first generation of his students, became central to the development of Sunni kaläm.

5 For background, see Madelung, The early Murji'a, and Rudolph, Al-Māturīdì 24-25.

6 See Rudolph, Al-Mäturīdī 27; also van Ess, Theology and society i, 176-184. 
This, in turn, means that we can speak not only of a Hanafi legal but also theological school, which later developed into the Maturidi school of theology, but only well after Abū Manșūr al-Māturīdī himself was active. ${ }^{7}$ The Hanafi and Maturidi theological views that became dominant in Khorasan and Transoxania in the third/ninth century continued to dominate in this region, at least until the eighth/fourteenth century.

How did Abū Hanifa view the relationship between faith and knowledge? Or rather, what did early Hanafi and Maturidi scholars believe were his views on the matter? In the only text that modern scholars believe is authentically Abū Ḥaniffa's, which is a letter (risāla) written to 'Uthmān al-Battī, he insisted that faith excludes deeds, that it cannot increase or decrease, that all people and angels are equal in their imann, and that sinners will be judged only in the afterlife. ${ }^{8}$ However, in another text attributed to Abū Ḥanīfa, Kitāb al-Ālim wal-muta'allim, which was actually authored by one of his followers, he is cited as mentioning other topics that will become central to the teachings of the later Hanafis, such as the importance of knowledge ('ilm, ma'rifa) which is equated to assenting (tașdiq $)$ to the truth of the faith and achieving certainty (yaqin) in belief. ${ }^{9}$ This emphasis on knowledge, as synonymous with $\bar{m} \bar{a} n$, raised the question as to its scope and nature. Abū Ḥaniffa suggested in his Risāla that Muhammad asked people "to bear witness that there is no god but God alone who has no partner, and to acknowledge what he [Muhammad] has brought from God." In the Kitāb al-Figh al-absat, one of the most important early Hanafi sources authored by a student of Abū Hanīfa, ${ }^{10}$ the master is cited using the so-called Gabriel hadith to explain what it is that Muhammad brought from God: a message on belief in the oneness of God, the prophethood of Muhammad, the angels, the Holy Scriptures, the earlier prophets, the Last Judgment, and predestination. As his interpreters understood it, Abū Hanīfa demanded

7 On the Hanafi theological school, see Rudolph, Al-Māturīdī 29; van Ess, Theology and society i, 219-229; Watt, Islamic philosophy 23. Although belonging to the Hanafi legal and theological school (the latter later becoming known as Maturidism) mostly went hand in hand, it is known that some later Mu'tazilites belonged to the Hanafi legal madhhab, for instance. This was especially true after $230 / 85$ o when Mu'tazilism became a purely theological doctrine, separate from politics and jurisprudence. See Watt, Islamic philosophy 106. On the reasons why Maturidites referred to themselves as aṣhab Abi Hanīfa as late as the fifth/eleventh century, see Rudolph, Al-Mãturīdī 5-7.

8 Rudolph, Al-Māturīdì 28-36.

9 Rudolph, Al-Māturìdī 48-53; van Ess, Theology and society i, 231. This text was actually authored by Abū Muqātil al-Samarqandī (d. 208/823).

10 Figh al-absaț was authored by Abū Muțị al-Balkhī (d. 199/814). See Rudolph, Al-Māturīdī $53^{-}-58,65$. 
knowledge of God and of the Prophet, as well as acknowledgment of what the Prophet brought from God in a summary manner (jumlatan), without a detailed explanation. ${ }^{11}$ Furthermore, as is elaborated in a later commentary (probably from the late fourth/tenth-early fifth/eleventh century) on Figh alabsat, Abū Haniffa was said to have endorsed the faith of an imitator or person who accepts faith on authority of others (muqallid), because he viewed anyone who acknowledges Islam in a broad and general sense, even without knowing anything about the book, the creed, or religious duties, as a believer. However, he also acknowledged that a faith based on inference (istidla $\bar{a} l$ ) and reasoning is a thousand times more superior and enlightened than the one based on imitation. ${ }^{12}$

This last issue, of whether or not imitative faith, or faith based on what one learns on the authority of others rather than through one's own reasoning, was valid or not became a polemical trope well established in kaläm works by the mid-fourth/tenth century and directly addressed by Abū Manșūr al-Māturīdī, Abū Hasan al-Ash'arī, as well as the Mu'tazilites. The issue was clearly of utmost importance to al-Māturīdī, who begins his Kitāb al-Tawhìd with a question of epistemology and quickly comes to the issue of belief based on authority (taqlid), which he identifies as the cause of all error and reason for the existence of false beliefs. ${ }^{13}$ Building on Hanafi tradition that emphasized knowledge and the capacity of the ratio to know the truth, al-Māturīdi maintained that the intellect was capable of proving God's existence based on his creation. In light of this confidence in the powers of the intellect, it is not surprising that alMăturīdī himself rejected the validity of imitative faith in no uncertain terms and postulated that only faith based on inquiry (nazar) with one's own intellect ('aql) and consideration of proofs (burhān) was valid. ${ }^{14}$ For al-Māturīdī, reasoning (istidlāl) was thus a precondition for $\bar{i} m \bar{a} n$.

11 Van Ess, Theology and society i, 232; Izutsu, The concept 118.

12 The commentary on Fiqh al-absaț was attributed to various authors, including al-Māturīdī himself and Abū l-Layth al-Samarqandī (d. 373/983), but it is not conclusively proven who authored it. Van Ess and Rudolph have convincingly argued that what Wensinck (in The Muslim creed 123) thought was the Sharh Fiqh al-akbar I, was actually Sharh Fiqh al-absat. See van Ess, Theology and society i, 237-241; Rudolph, Al-Māturīdī 57. For a close analysis of this commentary and discussion of its authorship, see also Daiber, The Islamic. For the commentary on Abū Hanifa's view on taqlīd, see ibid., 68-75, 222-224. The metaphor of light $(n \bar{u} r)$, likely of Sufi origin, was characteristic of the Maturidi conception of imān that served to offset the Murji'i insistence on equality of ìmān-everyone's ìmān was the same in essence and could not increase or decrease but it could be more or less enlightened. On this, see also Izutsu, The concept 121-122.

13 Rudolph, Al-Māturīdī 231.

14 Ibid., 231-232. Also see Rudolph, Ratio und Überlieferung 79. 
This, in turn, forced later Hanafi-Maturidis to try to reconcile the tension between Abū Ḥanifa's position on the subject, which was largely interpreted as an endorsement of the faith of a muqallid and reasoning in general terms as sufficient for being considered a mu'mīn, and al-Māturīdì's position that explicitly rejected imitative faith and favored thinking in terms of particulars as a precondition for having $\overline{i m a} n$. Like the commentator on Figh al-absat, they did so by trying to emphasize Abū Hanīfa's praise for faith based on reasoning. Others, like the later Bukharan Maturidi scholar Nūr al-Dīn Șābūnī (d. 580/1184) in his al-Bidāya fì uṣūl al-dīn, reported that Abū Ḥanīfa viewed a person who refused to engage in reasoning in order to improve their understanding of faith as a rebel and a sinner. ${ }^{15}$ While Maturidi scholars generally agreed that the faith of the muqallid is valid, this attempt at reconciliation of Abu Hanifa's and alMāturīdì's positions may have given rise to some ambiguity in their definition of necessary knowledge. For instance, in the foundational text of Maturidi theology, Abū l-Yusr Muhammad al-Pazdawìs (d. 493/1099-100) Ușūl al-dìn, the author stated that ahl al-sunna wa-l-jamã $\bar{a}^{\mathrm{c}}{ }^{16}$ maintained that summary faith (al-imān bi-l-jumla) is necessary (wäjib), while the detailed faith (al-imān bi-ltafāsăll) is not required, except when one is confused about an issue and needs a clarification. It is sufficient to say "God is one and has no partner; Muhammad is his servant and Prophet. Everything that he brought from God is true." He contrasts this to the views of the Mu'tazilites, who maintained that detailed faith was necessary, and the Ash'arites, who also reportedly held the same view. At the same time, however, when expounding the view of the ahl al-sunna wal-jamā' $a$ in more detail, Pazdawi refers to the Gabriel hadith and implies that the Prophet's response to the angel's question "What is imann?" (i.e., that imān is belief in God, his angels, books, prophets, resurrection after death, and that all is owing to God) is the summary faith, which suggests that there was some equivocation in the Maturidi stance on what that minimum knowledge of faith was that qualified one as a believer: a simple profession of faith (shahäda) or the articles of faith enumerated in the Gabriel hadith. ${ }^{17}$

Al-Māturīdì's views did not greatly differ from al-Ash'arī's or the Mu'tazilites', who also maintained that reasoning was necessary for having $\bar{i} m \bar{n} n .{ }^{18} \mathrm{Al}-$

\footnotetext{
15 es-Sâbûnî, Mâtürîdiyye akaidi 181.

16 In this context, the ahl al-sunna wa-l-jamāa are Hanafites (and Maturidites). On the process by which the Hanafites-Maturidites came to assume this label, see Rudolph, AlMāturìdī 61 niz3.

17 I am using the Turkish translation of Pazdawī’s Ușūl al-dī. See Pezdevî, Ehl-i sünnet akâidi 233-235.

18 On convergences on this issue, see Rudolph, Ratio und Überlieferung; Frank, Knowledge
} 
Ash'arī, himself a former Mu'tazilite, and his followers believed that to assent (tașdīq) to what is reported ( $a k h b \bar{a} r$ ) by the community as truth requires some reflective distance from the proposal itself. ${ }^{19}$ As a later Ash'ari theologian, alBaghdadī (d. 429/1037), reports, al-Ash'arī said that the person who believes the truth on authority of others (taqlïdan) was neither a mushriq (idolater, polytheist) nor a käfir (unbeliever). When asked whether such a man was a believer (mu'min), al-Ash'arī replied that he would not call such a person a believer unconditionally, thus leaving the issue of his views on imitative faith open to interpretation. ${ }^{20}$ As Richard Frank showed, most Ash'ari theologians up to the sixth/twelfth century emphasized that reasoning is obligatory for one's assent to be properly founded. However, there was no unanimity among them regarding the precise character of this knowledge. ${ }^{21}$

Despite these convergences between al-Māturīdī's and al-Ash'arī's views, in later medieval polemical works their followers often came to be identified with diametrically opposing positions vis-à-vis the question of taqlìd and the issue of kufral-'ämma, although there was also some debate regarding al-Ash'ari’s positions. For instance, the commentary on Fiqh al-absat, which was very popular with later Hanafi authors, including Ottoman ones, specifically (and misleadingly) stated that both Ash'arites and Mu'tazilites rejected taqlïd and viewed the common masses as infidels. ${ }^{22}$ Pazdawī, on the other hand, asserts that a muqallid is truly a believer, and juxtaposes it to the view of the Mu'tazilites, who believe the opposite. He then says that reports on al-Ash'ari's views varied (but then states that the correct report is that he also believed that a muqallid is a true believer). ${ }^{23}$

Indeed, the later Ash'ari school did not present a homogenous position on the issue of taqlíd. Some, like the Maghrebi scholar Muhammad b. Yūsuf alSanūsì (d. 895/149o), maintained that reasoning is a condition for faith and that a person who remains at the stage of taqlid is not only a sinner but also an infidel in the eyes of God. ${ }^{24}$ Others tried to temper the radical nature of the thesis that an imitator is a sinner or an infidel or even dismiss it altogether. The Ash'ari theologians al-Ghazālī (d. 505/1111) and Fakhr al-Dīn al-

and taqlîd 40. On differences among Maturidi, Ash'ari, and Mu'tazili positions on this issue, see Izutsu, The concept 119-130.

19 Frank, Knowledge and taqlid 40-41.

$20 \quad$ Izutsu, The concept 121.

21 Frank, Knowledge and taqlid 47.

22 See Daiber, The Islamic 222. On the problem of ascribing the kufr al-ämma thesis to the Mu'tazilites and rejection of taqlid to Ash'arites, see Izutsu, The concept 119-121.

23 Pezdevî, Ehl-i sünnet akâidi 235.

24 El-Rouayheb, Islamic intellectual history $178,174-175$. 
Rāzì (d. 6o6/1210) rejected the accusation that Ash'arites denied the validity of the faith of the imitator and argued that a muqallid was neither a sinner nor an infidel and that the knowledge of detailed proofs about faith - typically the purview of a kalām specialist - was incumbent on the community, but not on every individual Muslim. ${ }^{25}$ In the second book of his Ihya 's 'ulüm aldin al-Ghazâli argued that in teaching the articles of faith, the goal is first to make a child or a novice memorize, then to understand, and finally to arrive at certainty in order to assent to what they have learned. Through his grace, God prepares a believer's heart without the necessity of arguments or proofs, and a believer accepts God's message upon instruction (talqin) and authority (taqlid). This carries the danger of straying from the truth, so in order to prevent doubts and deviations, these beliefs have to be strengthened by proofs. However, it is not necessary to learn kaläm and disputation in order to do so; rather, one should strive to deepen one's understanding of faith through reading the Quran and hadith and performing one's religious duties. To expose a novice to kaläm would be like hitting a healthy tree with an iron bar, unnecessarily exposing healthy and solid belief to doubt. He likens kalām to a potent drug - it needs to be given in doses and only when necessary. ${ }^{26}$ According to al-Ghazālī, while the study of kalām was not a religious duty incumbent on either individual Muslims (fard al-'ayn) or the community (fard al-kifāya) in the early days of Islam, by his time it has become a duty incumbent on the community—as long as there are some scholars who possess such specialized knowledge needed to defend the faith and refute opponents, the conditions are satisfied. In his view, laid out in the first book of his I $h y \bar{a}$, the learning that remains incumbent on each individual Muslim has to do with the foundations of belief, proper performance of worship, and awareness of prohibitions.

In contrast, we do not see such diversity in the views of Maturidi authors of later creeds that went on to gain great popularity in the Ottoman realms. The best known among them, Najm al-Dīn al-Nasafi's (d. 537/1142) 'Aqā̉id (or al-Aqida al-Nasafiyya), which was also included in the Ottoman madrasa curriculum, does not mention either the issue of imitative faith nor the issue of knowledge that is a precondition for one to be considered a believer. Nasafi simply defines imān as assent to what Muhammad brought from Allah and the

25 Ibid. 18o.

26 al-Ghazzālī, The foundations ii, Section II, available at: https://www.ghazali.org/works/gz -faith.htm (accessed on 19 May 2019). Al-Ghāzalī's attacks on philosophical kalām articulated in his various works induced scholars to believe that kalām was afterwards excised from Sunnism, giving rise to the so-called Ghazālī myth. This myth has been successfully challenged by scholars such as Frank Griffel, Khaled el-Rouayheb, and Heidrun Eichner. 
verbal confession of it. ${ }^{27}$ However, in his famous commentary on Nasafi's creed, Sa'd al-Dīn al-Taftāzānī (d. 793/139o), himself either an Ash'ari or a Maturidi strongly influenced by Ash'arism, states that assent (tașdiq ) with the heart to Allah's message is sufficient to bring one into the category of imān. He further states: "The degree of this kind of imān (al-imañ al-ijmālī) is no lower than that of detailed imān (al-imān al-tafșilli $).{ }^{28}$ Another Maturidi creed that later achieved great popularity in the Ottoman lands was the didactic poem entitled Bad' al-amālì by 'Alī b. 'Uthmān al-Ūshī (fl. c. 569/1173), which does not mention the issue of faith in general or in detail but states that "the faith of a person by imitating others is valid; there are clear-cut proofs favoring this opinion."29 Similarly, the topic of summary versus detailed knowledge of faith is not explicitly brought up in the creed by the Maturidi scholar Abū l-Barakāt al-Nasafi (d. 710/1310) entitled 'Umdat al-'aqìda li-ahl al-sunna. On the subject of taqlìd, he states that, contrary to what the Mu'tazilites say, the faith of a muqallid is valid because it entails assent (tașdīq), even if he is a sinner for not engaging in reasoning. ${ }^{30}$ This view is echoed also in Kitāb al-'Aqïda al-rukniyya by 'Ubaydallāh b. Muhạmmad b. 'Abd al- 'Azīz al-Samarqandī (d. 701/1301), another later Maturidi creed in which the author endorses the faith of the muqallid because it entails assent to God's message without any doubt or reservation. He understands the pronunciation of shahäda as assent to the divine message in general (ijmälan), while he refers to the Gabriel hadith to enumerate the articles of faith in detail. ${ }^{31}$

\section{2 \\ The Maturidi-Ash'ari Synthesis and the Question of İmān-i Taklīdì, İmān-i İcmālī, and İmān-i Tafṣ̂lì in Ottoman İlm-i hạals}

While the preceding paragraphs sought to map the general development and differences in Maturidi and Ash'ari views on the issues of taqlìd and knowledge

27 Watt, Islamic creeds 82.

28 al-Taftāzānī, A commentary 117. For a recent study of al-Taftāzānī's theology, see Würtz, Islamische Theologie.

29 Al-Ūshī, Bad' al-amālī 22.

30 See al-Nasafí, 'Umdat al-'aqìda. For the relevant passage in Turkish, see en-Nesefî, Islâm inancinin 61 .

31 See Bake, Ubeydallah b. Muhammed 9-10 (with facsimile of the relevant manuscript folios on 71). Samarqandī's text, which is recorded in the Turkish libraries under various names (al-Akaid, Risale fi'l-akaid; Şerhüll kelime-i şehadet, etc.) was published as es-Semerkandî, el-Akîdetür-rükniyye. 
necessary for one's faith to be considered sound, as the discussion chronologically approaches the Ottoman period, it is not only differences but also interactions and convergences between the two theological schools that have to be taken into account. Historical research on the development of both Ash'arism and Maturidism, especially in the so-called postclassical period, is only in its infancy, and the existing works often uncritically replicate the rhetoric of the sources themselves that strive to project an image of unity and homogeneity within a particular theological tradition rather than highlighting the diversity of opinions or interactions with other schools and traditions..$^{32}$ The nature of these interactions in the Ottoman period is only slowly being unearthed, but new research suggests that Ottoman scholars were well disposed toward a Maturidi-Ash'ari synthesis ${ }^{33}$ — a development that is also highlighted in Nabil Al-Tikriti's paper in this volume. After a period of intense infighting between the two schools in Khorasan in the pre-Mongol era and intense rivalries in Syria that followed the influx of the eastern Hanafi-Maturidi scholars into the traditionally Ash'ari terrain in the early Seljuk era, a rapprochement set in by the seventh/thirteenth century as the Zangids, Ayyubids, and later Mamluks sought to present a united Sunni Islamic front against the crusaders and Mongols. At the same time, the Mongol and Timurid rulers were ecumenical in their support of talented scholars regardless of their background, which allowed scholars in Central Asia to move more freely between theological schools as well as sectarian affiliations. Emblematic of this milieu was the rise of the philosophically minded scholars like 'Aḍud al-Dīn al-İjì (d. 756/1356), who followed the Ashari tradition, as well as Sa'd al-Dīn al-Taftāzānī and Sayyid Sharīf al-Jurjānī (d. 813/1413), who did not restrict themselves to ideas of only one school. ${ }^{34}$ These combined trends toward rapprochement between theological schools both to the east and to the southwest of the Ottoman domains directly influenced the formation of the Ottoman scholars, both through engagement with the texts and through personal study with the scholars involved in this rapprochement or their students. Ottoman literati were particularly drawn to al-Ghazālī's synthesis of theology, Sufism, Aristotelian logic, and law, and to the scholarship of the "post-Avicennian turn," especially works produced by scholars who integrated Sunni theology with different philosophical perspectives, including metaphysics, illuminationist philosophy, and Avicennian

32 On this point see Eichner, Handbooks 495-496; Rudolph, Al-Māturīdì 1-2O.

33 See Özervarl, Theology in the Ottoman lands 568; Badeen, Sunnitische Theologie.

34 On the process of rapprochement between Ash'aris and Maturidis between the fifth/ eleventh and eighth/fourteenth centuries, see Berger, The interpretation 694-695. 
ideas. ${ }^{35}$ The fact that this fusion between the philosophical and theological traditions of rational exegesis and the adoption of a language of philosophy and demonstration was particularly widespread among the Ash'ari-Shafi'i scholars of the seventh/thirteenth and eighth/fourteenth centuries meant that the latter's works were often cited by the Ottoman scholars coming in their wake. $^{36}$

However, it is not the kaläm of the post-Avicennian turn and the new questions it engendered that are central to the discussion at hand, but rather how they interacted with and informed the older theological inquiries regarding faith and knowledge. In the Ottoman polity, which by the early tenth/sixteenth century experienced a growing rate of conversions to Islam, managed a large non-Muslim and very diverse Muslim population, and faced the challenge of a rival Islamic polity with a different sectarian affiliation - the progressively more Shi'ite Safavid Iran - the question of who was a believer and what constituted knowledge of faith that would guarantee one's salvation in both this and the other world gradually came into a sharper focus. From the mid-ninth/fifteenth century onward, the ulama (religious scholars), whose services were increasingly indispensable to the expanding empire seeking to both credibly govern and garner prestige in the Islamic world, were gradually getting more integrated into the Ottoman administration and were both expected and sought to have a greater say in the matters of what constituted correct faith and practice of Islam. ${ }^{37}$ The degree to which the ulama became integrated into the Ottoman administration has been described by historians as unprecedented in Islamic history, creating a situation in which particular definitions of who was and what it meant to be a Sunni could be enforced with a new degree of authority (i.e., conditions for a formulation of "orthodoxy"). ${ }^{38}$ The convergence of these developments in the late ninth/fifteenth-early tenth/ sixteenth centuries thus led to a greater sensitization across Ottoman society to the questions of correct faith and practice.

35 Özervarl, Theology in the Ottoman lands 568; Spannaus, Theology in Central Asia 591. Ulrich Rudolph has studied an interesting example of how this trend extended even into jurisprudence, which can be found in the work of celebrated Ottoman jurist Molla Hüsrev (or Khusraw) (d. 855/1480 or 1481), who in his Mir'ät al-uṣülfi sharh Mirqāt al-wușül brings the Avicennan theory of intellect to bear on the reasoning behind defining a legal subject. See Rudolph, Al-Ghazālī 85-88.

36 For an excellent overview of the intellectual genealogies underpinning this process see Endress, Reading Avicenna.

37 On these developments, see Al-Tikriti, Kalam in the service of the state; Terzioğlu, How to conceptualize; Atçl, Scholars and sultans.

38 On the notion of orthodoxy in an Islamic context, see Ahmed, What is Islam? 270 and 297. 
While the higher echelons of ulama sought to promulgate this agenda through, by now, well-studied legal opinions ( fatāw $\bar{a})$, Ottoman literati of various educational levels and provenance, both affiliated and not with the government, started producing didactic literature on the foundations of $\bar{i} m \bar{a} n$ and Islam that would be comprehensible to common people in their own language, which for the majority of Ottoman Muslims in Anatolia and the Balkans was Turkish. It is in the context of these catechetical texts, which came to be known as 'ilm-i hạls, that Ottoman authors weighed in on the questions of imitative as well as general versus detailed faith. Although Ottoman 'ilm-i hă

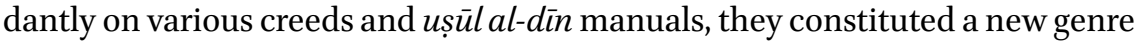
that often succinctly combined 1) the basic teachings on imān extracted from creedal literature with 2) the basic rules on worship derived from figh and its regulations for ritual obligations ( $(i b \bar{a} \bar{d} \bar{a} t$ ) and 3 ) the basic information on prohibitions derived largely from collections of legal opinions ( fatāw $\bar{a})$, in particular on utterances and actions that could render one an unbeliever (alfäz al-kufr; Tr. elfāz-i küfr). In this respect, the overall concept of the Ottoman 'ilm-i hă appears to fit squarely into the framework for knowledge incumbent upon each individual believer as envisioned by al-Ghazâlī (see above). This framework can be described as dogmatic in the sense that it emphasized unitary truth underlying the articles of faith and certainty of knowledge ( $\mathrm{i} / \mathrm{m}$ ) about them based on reasoning and incontrovertible textual proofs, while shunning speculation. In an important contrast to the medieval creeds, however, Ottoman 'ilm-i hăls included stipulations on worship and certain prohibitions derived from Hanafi law, thus reinforcing the notion that the boundaries of dogma are not only definite but circumscribable by law. As Norman Calder pointed out, while the books of law contained expressions of creed, medieval creeds did not contain references to law, which he, in turn, interpreted as the limits of the genre of creed to establish the boundaries of orthodoxy. ${ }^{39}$ Discursively speaking, Ottoman 'ilm-i hạ $\mathrm{a}$ s were thus projecting different claims than creeds, more in line with the new understanding of "orthodoxy."

The discussion of examples of blasphemous utterances and actions covering a wide range of issues was typically found in the sixth/twelfth-century and later legal manuals-cum-collections of juridical opinions-such as Fatāwa $l$ Qädīkhān (late sixth/twelfth c.), al-Fatāwā l-Tatärkhāniyya (eighth/fourteenth c.), al-Fatāwā l-Bazzāziyya (ninth/fifteenth c.), etc.—produced by the eastern Hanafites who seem to have had a penchant for this issue, in contrast to their colleagues - both Hanafi and otherwise — in other parts of the Islamic world. ${ }^{40}$

39 See Calder, The limits 225.

40 Intisar Rabb argues that among the four Sunni schools of law, only in Hanafism did 
At least since the mid-eighth/fourteenth century, when the Khwarazmian Hanafi scholar Badr al-Rashīd (d. 767/1366) produced a treatise on alfäz alkufr, there were also copies of stand-alone works dedicated to the topic. ${ }^{41}$ This eastern Hanafi penchant for the alfäz al-kufr tradition is important because it appears to have served as the basis for rethinking of the boundary between imān and kufr in the Ottoman Hanafi school in the early 140os. The most emblematic indicator of this rethinking, which emerges in the Ottoman context by the $1450 \mathrm{Os},{ }^{42}$ was a legal innovation stipulating that one should renew one's faith (Tr. tecdìd-i imān) upon committing an act or uttering something deemed blasphemous by the (eastern) Hanafi jurists. This development is traceable through the fatāw $\bar{a}$ promulgated by the muftis from the lands of Rum (i.e., Anatolia and Rumeli) who were affiliated with the Ottoman government, but it is not evident in the fatāwa of the Hanafi jurists not affiliated with the government, especially from the Arab provinces, which underscores the existence of intra-Hanafi, interregional differences. In view of the scholars from Arab provinces of the empire, this stipulation amounted to takfirthe act of declaring other Muslims infidels (käfir) - which was considered contrary to the Sunni tradition and was singled out as such in a number of medieval Sunni creeds, including Hanafi ones. ${ }^{43}$ In another unprecedented move, the Ottomans elevated the Hanafi school of law into a state madhhab by the tenth/sixteenth century; however, given these regional differences and both intra- and inter-madhhab tensions that this move caused, the question

defamation require enforcement of criminal sanction, and speech acts were perceived as having the potential to violate public values. Because Hanafi jurists regarded public values to be at stake in the commission of all crimes, including defamation, they likewise regarded enforcement as a state obligation, one that could not be left to the whims of an individual pardon. Defamation was defined as violation of one of God's rights because it compromised their sense of Islam's public values. Blasphemy was one type of defamatory crime. See Rabb, Society and propriety 447 . However, it appears that a more limited category of blasphemy, specifically against the Prophet and the Companions, also emerged in the Shafi'i legal thought by the eighth/fourteenth century in Mamluk Syria and Egypt, most likely as a response to the Sunni-Shi'i tensions. Interestingly, it was Taqi al-Dīn alSubkī (d. 755/1355), the Shafi'i scholar who promoted an Ash'ari-Maturidi synthesis, that was the main voice of this new discourse on blasphemy, partially inspired by the Hanafi sources. See Wiederhold, Blasphemy against the Prophet.

See Ökten, Why ordinary utterances. I thank Ertuğrul Ökten for sharing his unpublished article with me.

The earliest reference to the practice that I could trace so far can be found in Yazıcızāde (Yazıcıoğlu) Mehmed's Muhammediye, which was written in 853/1449. See Yazıcıoğlu, Muhammediye ii, 459 .

43 On this issue see Burak, Faith, law and empire. See also Meshal, Sharia, for the reaction of the Egyptian jurists to what they perceived as the Ottoman propensity toward takfir. 
arises as to the nature of this Hanafism. ${ }^{44}$ Ottoman 'ilm-i hạ $\bar{a}$ authors' takes on the relationship between knowledge and faith shed an important light on this question.

The genre of 'ilm-i hăl crystalized only gradually from the early fifteenth century onward and reached its heyday in the seventeenth century. ${ }^{45}$ The aforementioned penchant of the Ottoman scholars for al-Ghazāli and the scholarship of the post-Avicennian turn, as well as for seamlessly integrating Maturidi and Ash'ari views on certain questions, is on full display in the first 'ilm-i ha $\bar{a} l$ written by an Ottoman scholar, Kuṭbe'd-dīn İzniḳ̂’s (d. 821/1418) Muḳaddime (Introduction). İznikī was a product of the early Ottoman scholarly environment in Anatolia. He was likely a Sufi but wrote on subjects that range from tafsìr and hadith to fiqh, kalām, and Sufism. ${ }^{46}$ Like al-Ghazāī in his Ihyyä, in the preface to his work İzniki introduces the division between the knowledge incumbent upon the individual and knowledge incumbent upon the community, stating that in the Mukaddime he set out to provide in easily understandable Turkish the knowledge that every Muslim needs to have and without which his or her Islam cannot be complete. He states that one's Islam cannot be complete without knowing and performing the five pillars of Islam, which serve as the organizing principle of the work-he devotes a chapter heading $(b \bar{a} b)$ to each, followed by a discussion of virtues to which one needs to aspire and vices one needs to avoid in order to be a true believer. ${ }^{47}$ Importantly, he emphasizes the fact that some obligatory knowledge needs to be internalized while some needs to be externally performed. He points out that law books do not consider the internal aspects of obligatory knowledge because they are concerned with whether people externally conform to the requirements of the law. Thus, they are not interested in a person's morality and what goes on in their heart, which is why some scholars undertook to teach believers how to achieve closeness to God. He gives the examples of al-Ghazālī, al-Rāghib alIṣfahānī (d. 502/1108; an Ash'ari and Shafi'i scholar and "ethicist of the soul"), ${ }^{48}$ the famous Sufi scholar al-Qushayrī (d. 465/1072), and Abū 'Abdallah al-Ḥārith

44 On the elevation of the Hanafi madhhab into a state madhhab, see Burak, The second formation; on inter-madhhab tensions that this caused, especially in post-conquest Cairo, Damascus and Aleppo, see Meshal, Sharia; and Fitzgerald, Murder in Aleppo. On this process, see Kelepetin Arpaguş, Bir telif türü; Aynacı, Osmanlı kuruluș dönemi; Krstić, Contested 29-35; Terzioğlu, Where 'ilm-i hăl.

46 Öngören, Kutbüddin İznikî, TDV IA, xxvi, 485-486; Üstünova, introduction to Kutbe'd-dîn İznikî, Mukaddime 21-25; Kartal, Kutbuddin.

47 Kutbe'd-dîn İznikî, Mukaddime 139-141.

48 On al-Rāghib al-Ișfahānī's ethics of education and its impact on al-Ghazālī, see Mohamed, The Ethics, and Mohamed, The virtue. 
al-Muhāsibī (d. 243/857), another eminent Sufi and rationalist theologian who advocated constant self-examination. ${ }^{49}$ This aspiration to instruct believers on how to cultivate both the internal forum focused on imān and the external forum focused on practice ('amel) became a template for the later Ottoman 'ilm-i ḥăls as well.

Devoting his first chapter to īmān, İzniḳ̂ uses the Gabriel hadith to introduce the basic articles of faith. He states that $\bar{c} m \bar{a} n$ consists of six items-belief in oneness of God, his angels, his books, his prophets, the Day of Judgment, and predetermination - and emphasizes that it is necessary to know each of these six items in detail (bu altı nesneyi birer tafșill idüp bildürmek gerek). ${ }^{50}$ Having explained each article of faith in detail, İzniḳi anticipates hypothetical questions from his audience. Crucial for the discussion at hand, he includes the following issue: if it is compulsory to know these six things, what happens to those people who know nothing of God or his prophet, of imān and Islam, before becoming Muslims? How can this be reconciled with the hadith that Muhammad promised anyone who pronounces the shahāda that they would enter Paradise? İznikī responds that Muhammad indeed proclaimed that the faith of those who pronounce the shahäda is sound because he wanted to facilitate people coming to faith. Shahäda epitomizes belief in those six things (bu altı nesneyi mücmelen bilüp): by saying it, one professes belief that God is one, that Muhammad is his prophet, and that everything he brought from God is true. Here, İznikī is trying to reconcile his view that faith should be known in detail with the well-known hadith that assenting to faith in general through pronouncing the shahāda is sufficient for being considered a believer and entering Paradise.

He returns to the issue of general versus detailed knowledge in a later passage when discussing the oneness of God. He states that ulama are in disagreement whether or not one should know proofs of God's oneness in general or in detail. He acknowledges that the Prophet himself accepted the faith of those who were ignorant in details of faith and God's oneness, but then he invokes the report on Abū Haniffa's saying that those who do not know proofs of God's oneness (tevhīid) are rebels ('ạsī). İzniḳi continues by saying that it may be that commoners ('âmmi kişiler) who become Muslims at first do not understand the proofs of tevhìd, but they should strive to deepen their understanding by seeking explanation - those who have the capacity to understand but do not learn are rebels ('ạṣı̄ ) and sinners (günāhk $\bar{a} r)$. He then cites al-Ghazālī to say

49 Kutbe'd-dîn İznikî, Mukaddime 142. I thank Professor Özervarlı for clarifying the misreading of al-Muhāsibī's name in Üstünova's transliteration.

50

Ibid. 145 . 
that if someone becomes a Muslim, but God's oneness and greatness is not in his heart, he will have the benefit of such imān only in this world. A confirmed believer is only the one with immān in his heart. ${ }^{51}$ Besides al-Ghazālī, who is clearly İzniḳ̂̀'s model, he cites also the Ash'ari scholars Fakhr al-Dīn al-Rāzì and 'Aḍud al-Dīn al-İjì's Kitāb al-Mawāqiff fí ilm al-kalām. ${ }^{52}$ Al-İjì's Mawāqif, in particular, was a vociferous defense of rational theology (kalām), which al-İji describes as the most exalted discipline of learning from which all other learning derives. Al-ījī also extols reasoning and knowledge of kalām as a means of climbing out of the pit of blind imitation to reach the peak of certainty in faith. ${ }^{53}$ Even though İznikị is careful to maintain a balance between the various sources, theological views (he often cites and carefully considers what he presents as the Mu'tazili position, along with the Ash'ari and Maturidi ones), and "hermeneutic resources" 54 of Islam (kalām, fiqh, Sufism, etc.) on which he is drawing in his presentation and point to the disagreement among scholars on various issues, it is clear that he was sympathetic to the idea of demanding greater knowledge of faith and greater commitment in performance of religious duties from common believers. One can detect the influence of Ash'ari views on İznikīs conceptualization of the relationship between faith and practice. He states that in the view of the Sunnis (ehl-i sünnet ve'l-cemāat), works do not determine whether or not one will enter Paradise or Hell; however, he then embarks on an elaborate discussion of why it is naïve to believe that one can do just anything, including fail to perform worship, and then repent and enter Paradise. For İznikī, practice is reflective of inner belief, in which respect he seems to be closer to the Ash'ari than to the Hanafi-Maturidi school, which more decisively compartmentalized imān and 'amel and argued against the latter affecting the former. ${ }^{55}$

Although İznikī emphasizes the importance of fear of God, he is more interested in inducing his audience to embrace the necessary knowledge without

$51 \quad$ Ibid. 165 .

$5^{2}$ On al-Rāzi, ibid. 147; on al-Ījīi, 154.

53 See van Ess, Die Erkenntnislehre 44; also Cürcâni, Şerhu'l-Mevâkıf i, 146.

54 This is Shahab Ahmed's term. See his What is Islam?

55 Izutsu, The concept 143. According to al-Shahrastānī, al-Ash'arī understood the "doing" of religious duties as a kind of tașdiq in the sense that doing was an outward indication of one's mental assent. Works ('amal) do not enter into imān as a pillar, and the absence of 'amal does not turn a man immediately into a käfir, but on the other hand, 'amal is not extraneous to imān in such a way that he who neglects 'amal may be said to deserve no punishment and chastisement in the next world. Ibid. 161. Al-Ghazāli also maintained that practice affects inner conviction and helps the conviction take deeper root in the soul. 
overemphasizing the danger of lapsing into küfr. The focus is on a positive definition of faith and what one can do to cultivate and grow it, as well as on which vices to avoid in order not to weaken it. However, İznikī does not include an extensive section on elfäz-i küfr, which will become staple in later 'ilm-i hạalshe simply refers his readers to the collections of juridical opinions where they are discussed in detail. ${ }^{56} \mathrm{He}$ emphasizes that a believer who has committed a sin should quickly repent and cites the prophylactic prayer one should recite every day to protect oneself from şirk and küfr. But, he does not refer to the legal solution that seems to have been in development during the first half of the fifteenth century among the Ottoman legal scholars, namely that one should both repent and renew one's faith (tecdìd-i imānn) as a consequence of falling into küfr. He also states that no one among the "people of the qibla" (i.e., those praying in the direction of Mecca) should be labeled a käfir, except when they deny some aspect of belief or a verse of the Quran, or when they say things that jurists consider blasphemous. In this respect, İzniḳıs work, written in the first half of the fifteenth century, before the onset of a more concerted politics of defining and enforcing a Sunni orthodoxy and orthopraxy, reflects a more relaxed, "spacious" concept of imān in which one is not in constant danger of transgressing the boundary with küfr, which is the sense we get from some later Ottoman ilm-i hạals.

İznikị’s Mukaddime continued to be a popular catechism well into the tenth/ sixteenth century, along with various other works in Turkish that were composed or translated for the growing Ottoman Muslim community. However, a new crop of 'ilm-i hāals began to be produced starting in the 1540s, in the heyday of Sultan Süleymān's attempts to highlight the empire's commitment to and defense of a Sunni orthodoxy, especially through legal discourse and elaborate architectural projects. Multiple state and nonstate agents engaged in the process of instilling a greater commitment to Sunnism in Ottoman Muslims while simultaneously trying to define its content and boundaries in this particular moment in time. ${ }^{57}$ Three texts will be of particular interest to us here: İmādüllİslām (The pillars of Islam) by 'Abdu'r-rahmmān b. Yūsuf Aksarāyī, Lüț̣i Pasha's

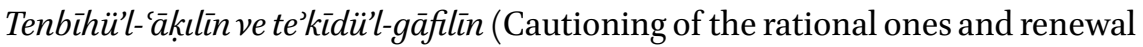
of request to the heedless ones), and Mehmed b. Pīr 'Alī Birgivìs Vașiyetnāme (Testament).

Aḳsarāyì's '̇māaü̈l-İslām became extremely popular soon after being written around 949/1543, to which numerous surviving tenth/sixteenth-century

$5^{6} \quad$ Kutbe'd-dîn İznikî, Mukaddime 154.

57 I have discussed this phenomenon in greater detail in Krstić, State and religion. 
copies of the text testify. ${ }^{58}$ We do not know anything about Aksarāyī himself, except that he based his work on an earlier text in Persian by an 'Abd al-Azīz Fārisī, entitled 'Umdāt al-islām, but with extensive additions as well as omissions, and the final product being presented in simple Turkish. Like İzniḳīs Mukaddime, it is primarily focused on the five pillars of Islam, but in addition to devoting chapters to faith (immann), prayer (namāz), fasting (oruc), alms giving (zekāt), and pilgrimage (hac), it has further chapters on death, torments of the grave, the afterlife, the rights (of parents, children, spouses, neighbors, etc.), and etiquette $(\bar{a} d \bar{a} b)$. Aksarāyì opens the first book, devoted to faith, by saying that in the opinion of the legal experts, it is the detailed faith that is valid, which is why he sees it necessary to explain what this detailed faith is. He states that according to Ta'wilät al-Käshānī, a mystical-philosophical work of tafsìr written c. 729/1329 by a Tabrizi scholar 'Abd al-Razzāq al-Kāshānī (d. c. 730/1330), a specialist in Ibn 'Arabī's metaphysics, faith can be of two kinds: imitative (taklīdi $)$

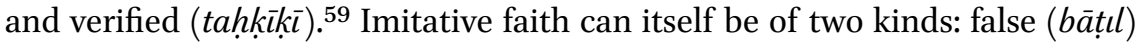
and sound (șahịh). False taklìd is when someone says shahāda, thinking "here are some words that everyone is saying, but I know nothing else besides" - such a person cannot be considered a true believer (mümin). Sound taklïd is when someone understands that those who are saying the shahāda will be saved from the poll tax $(h a r a \bar{c})$ in this world and from the torments of the grave in the next one, and he says shahāda because he desires the same. However, Aksarāyi proceeds to elaborate, in the Cāmi'ül-fetāva it is said that the imitator's faith is accepted, but because he is rejecting the reasoning, he is considered a sinner ('ạșī). ${ }^{60}$

He proceeds to say that verified faith (tahkikki imān) can also be of two kinds: based on reasoning (istidlālī) and based on perception (zevkī ). Drawing on alGhazālì and Sharîf al-Jurjānī, he explains that the faith based on reasoning is when one looks upon the world and sees that it is built on a sound basis and contemplates everything that is created upon it to realize that it must not have come into existence on its own and that there must be an excellent master builder/creator of unparalleled power behind it. Such a person then begins to recognize the power of this creator in all its characteristics (sılfatlar) and that everything that exists is thanks to him. A person that comes to realize and

$5^{8}$ On this text, see Kelepetin Arpaguş, Osmanlıve geleneksel İslâm 65-109. See also her article on "İmâdü'l-islâm" in TDViA, xxii, 172-173.

59 Akssarāyī, İmāiü'l-İslām $10 a$.

6o Cāmi'ül-fetāva is a Hanafi legal manual-cum-collection of juridical rulings compiled by Kurḳ Emre Meḥmed b. Mușțafā al-Ḥamīdī al-Ḳaramanī (d. 879/1475). For more details, see Hira, Bir katalog yanıltması. 
accept God's existence and oneness and subjects to it completely in his or her heart and soul can be said to have attained faith based on reasoning. ${ }^{61}$ As for zevkīimann, he says that it is not very productive to discuss it with common people ('avām). ${ }^{62}$

Upon introducing types of imān, Akssarāyī moves into explaining its conditions, using mostly fatwa collections as a source to emphasize that any Muslim man or woman who reaches puberty and is not familiar with the basics of faith cannot be considered a believer, and if, when asked to state the basics of faith, they respond with "I do not know," they are to be considered unbelievers (käfir). He refers to the Cammi 'ü'l-fetāv $\bar{a}$ that counsels heads of the households how to teach their dependents about the basics of faith. "Do not ask the members of your household questions about God's oneness, because it is possible that they would respond with 'I do not know', which would make them unbelievers. Rather teach them in this way: 'This is a stipulation of God's oneness, isn't it?' Then they can respond: 'Yes.' This is how you should teach them."63

Before discussing the actual content of the articles of faith, Aksarāyī stops to make the final distinction, between faith in general (mücmel imañn) and faith in detail (mufașal imānn). The first one he explains as saying "I believe in God with all his attributes and names, and I accept all his commands." The second one, he says, has seven pillars, each of which needs to be enumerated: "I believe in Allah, His angels, books, prophets, the Day of Judgment, that everythinggood or bad-is from Him, and that there will be resurrection." He writes that according to Kashf al-asrār, 'Abd al-'Azīz al-Bukhārī's (d. 730/1330) commen-

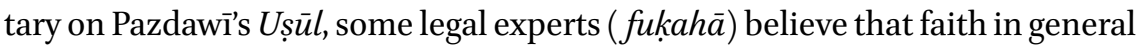
is valid. However, according to the theologians (mutakallimūn), it is the detailed faith that is valid, not the summary one. He refers to the Ashari theologian Abu Bakr al-Bāqillānīs (d. 403/1013) Kitāb al-Tamhìd in which it is said that every person should know their faith in detail. ${ }^{64}$ Consequently, Aksarāyi writes, he also saw it fit to explain the faith in those terms so that everyone would learn the basics and their faith would not be deficient. He then finally moves into the detailed discussion of the articles of faith, within which he also includes a section on the beliefs that distinguish Sunnis (ehl-i sünnet ve'l-cemä'at) from other sects, such as Kharijites and Shi'ites (Rājlizi $)$.

The last part of the chapter on $\bar{i} m \bar{a} n$ deals in great detail with the elfāz-i küfr. The examples cover a wide range of issues, from utterances-especially

\footnotetext{
61 Akssarāyī, '̇̇mādül-İ̀stām 1ob-11a.

62 Ibid. 11b.

63 Ibid. 13a.

64 Ibid. 14a.
} 
jokes - about the practices and beliefs of Islam, the prophets, God, and the ulama, to utterances in social interactions between friends, spouses, etc. on various topics. For instance, if an infidel approaches someone and says, "Teach me Islam so that I can become a Muslim" and that someone responds, "Go to such and such scholar [so he can teach you]," the latter person is a käfir because anyone who allows another person to remain in unbelief any longer than necessary is an unbeliever him/herself. Or, if someone says, "Don't play chess, because scholars say that those who play chess are the enemies of Allah" and another responds, "If for this reason I am to become an enemy, so be it," he becomes a kāfir. Or if someone says "Bismillāh" when about to take a sip of wine, that person is an unbeliever. ${ }^{65}$ Based on the fatwa collections he used, Aksarāyī stipulates that anyone who has uttered blasphemous words should immediately reject them (rücū'etmek) and renew their faith (tecdìd-i ìmān) ${ }^{66}$

In sum, although he is using a variety of sources authored by both Hanafi and Shafi'i, Maturidi and Ash'ari scholars, when it comes to the issue of $\bar{\imath} \bar{a} \bar{n}$, Aksarāyì's 'ilm-i hăal emphasizes two particular ideas that are echoed in other Ottoman ilm-i hạls of the tenth/sixteenth and eleventh/seventeenth centuries but are not featured in the medieval Hanafi-Maturidi creeds. One of those seems to be influenced by the Ashari theological tradition: in order to be valid in the afterlife, one's faith should be detailed (although from the legal standpoint general faith is sufficient to render one a Muslim). Related to this is also Aksarāyi's view that although an imitator's faith is technically acceptable, the latter is a sinner because he rejects reasoning, with faith based on reasoning being extolled as ideal. The other major idea falls within the purview of the eastern Hanafi legal tradition and carefully circumscribes the boundaries of $\bar{m} \bar{a} n$ in a way that we do not see in the medieval creeds. It maintains that committing küfr is a clear and present danger and that identifying those who commit it, rather than being an issue that Sunni Muslims should shun, is in fact something for which one has to be on a constant lookout within one's own social circle.

The same two key ideas are channeled by another mid-tenth/sixteenth century author of a number of catechetical works in Turkish, one-time grand vizier of Sultan Süleymān, Lüțfì Pasha (d. 970/1563). ${ }^{67}$ In his Tenbihhül-'áḳllìn ve te'kìdül-gāfilin, Lüț̣i Pasha comes out strongly in favor of the detailed faith, which he defines as the knowledge of the six articles, in addition to God's

\footnotetext{
65 Ibid. 29a-33a.

66 Ibid. 33b.

67 For a detailed discussion of Lüțî Pasha's works and catechetical mission, see Krstić, A catechizing.
} 
attributes, as the only way to enter Paradise. He considers shahäda as a legal precondition for being a Muslim but as insufficient for attaining salvation and becoming a true believer (mu'mīn). Like Akssarāyī, Lüț̣i Pasha finds support for this position in the Hanafi fatwa literature, especially al-Fatāwa $l$ Tatärkhanniyya, which insisted on the necessity of being able to describe the contents of one's faith when asked to do so, lest one becomes a käfir. ${ }^{68}$ Lüții Pasha envisions potential situations for such questioning in a number of passages in his account, at one point referring to the Sura al-Mumtahana (The woman under questioning; Q 60: 10), suggesting that the new converts coming into the community should be questioned about their faith. Those whose faith is found deficient should receive further instruction, while those who explicitly say "I do not know" and thus fall into küfr should be made to renew their faith as well as their marriage vow in the case that they were married. Seeking to define precisely the content of the necessary knowledge he envisioned for salvation, Lüṭ̂i Pasha penned a short catechism in question-and-answer format that set out to teach in around 40 questions and succinct answers the basics of faith and worship. ${ }^{69}$

Although he was not madrasa educated, Lüțfī Pasha read widely, especially in figh but also in kalām, although he explicitly condemns speculative kalām along the lines already outlined in al-Ghazālī's Ihyy $\bar{a}^{\prime}$ as a potential source of unbelief and heresy (zandaqa) $\cdot^{70} \mathrm{~A}$ close reading of his works reveals a mind trying to grapple with the inconsistencies in the sources and reconcile the positions of the Hanafi-Maturidis, with whom he professed affiliation as a member of the Ottoman ruling elite, with the positions of the Ash'ari and Shafi'i scholars whose works he used extensively and clearly found inspirational. For instance, on the subject of ìmān-i icmāli and ìmān-i tafșìli, he tries to reconcile the Hanafi position, which favors the former, with the Ash'ari position, whose favoring of a more detailed knowledge of faith he himself endorsed. He refers to metn- $i$ Pezdevī (his Ușül al-dìn, one of the foundational Hanafi-Maturidi texts), saying that it states that imann is based on two pillars: knowing the six articles of faith, on the one hand, and assenting to them in one's heart and professing them with the tongue, on the other. ${ }^{71}$ Only such a person will be saved from Hell. But then he refers to the Ash'ari scholar Ibn al-Ahdal (d. 855/1451) who,

68 Lüțī Pasha, Tenbīhül-'āḳılīn 9b, 44b-45a.

69 On this work see Krstić, From shahāda to 'aqìda.

70 Lüțī Pasha, Tenbīhül-'āḳılìn $7 a$.

71 Pazdawī indeed implied that ìmān-i icmāl $\bar{\imath}$ is the belief in the six articles of faith enumerated in the Gabriel hadith, and stated that knowing this is sufficient, and that it is not necessary to know further details. See Pezdevî, Ehl-i sünnet akâidi 234. 
in his Kitāb Kashf al-ghițā' 'an ḥaqāiq al-tawhìd, stated that when one knows one's faith in this many details and attributes, it is called imañn-i icmāl-i mufașșal, or detailed general faith. Lüți Pasha proceeds to explain that in his own work he referred to such faith as imman-i tafșilli in order to distinguish it from what the mutakallimūn of olden times labeled as imann-i icmāli (i.e., the sha$h \bar{a} d a) \cdot{ }^{72}$

Lüțĩ Pasha's fidelity to, yet apparent intellectual discomfort with, some aspects of the Hanafi positions on matters of faith particularly comes through in his discussion of the faith of the imitator, where he repeatedly extols the importance of knowledge and reasoning for achieving certainty in faith and condemns blind imitation, only to default to the well-known Hanafi position that an imitator's faith is acceptable. In fact, his discussion remains more faithful to al-Māturīdì's own championing of reason, which led him to condemn taqlìd, and Lüṭ̂î Pasha cites al-Māturīdì's sayings in a number of places, mostly based on reports of other scholars, like Abū'l-Hasan al-Rustughfanī (d. ca. 350/961), one of al-Māturīdì's students. ${ }^{73}$ Even though he duly acknowledges and accepts Abū Hanīfa's inclusive position on taqlïd, by consistently juxtaposing ìmān-i taḳlìdì as potentially leading to Hell with ìmān-i tafșìlì, which he sees as leading to Paradise, Lüțfì Pasha makes it clear that in his view the threshold for being considered a mu'min is considerably higher than for some of the earlier adherents of the Hanafi madhhab. At the same time, for all his championing of faith based on reasoning and knowledge, he is careful not to go to the other extreme and endorse the notion of kufr al-ämma, like the slightly younger North African Ash'ari scholar al-Sanūsī. In fact, he explicitly rejects this idea as Mu'tazili and focuses on the importance of learning and instruction for common people. ${ }^{74}$

In contrast to Aḳsarāyì's and Lüṭ̂i Pasha's views, Birgivī (or Birgili) Meḥmed Efendi (d. 981/1573), the author of by far the most popular Ottoman catechism in Turkish, entitled Vașiyetnāme (970/1562-1563), stated briefly and without elaboration that ìmān-i icmāli is sufficient (käfídür) and that imān-i tafșìli is not necessary. He writes that if someone knows the necessary things and believes in them but cannot explain them in detail, their Islam is still valid (hükm olunur). He also maintains that the imitator's faith is sound, without discussing any circumstances when it may not be so. ${ }^{75}$ However, in his more elaborate catecheti-

72 Lüții Pasha, Tenbihhüll-āǩkılìn 21a-b.

73 Rudolph, Al-Māturīdī 140-144: Lüț̣i Pasha, Tenbīhül-'āḳılīn 43b-44a.

74 Lüț̣i Pasha, Tenbihnül-'áḳılìn 43b-45a, 15b-17a.

75 Birgili, Vasiyyet-name 104. For a detailed discussion of Birgivi’s catechetical outlook, see also Tezcan, A canon of disenchantment. I am grateful to Baki Tezcan for sharing a draft 
cal work, al-Tarīqa al-Muhammadiyya, which he wrote in Arabic just before his death to address not only the basics of faith and practice but also a variety of other topics related to piety and moral living, Birgivi specifies that the faith of the imitator is true but that he is a sinner if he gives up reasoning. ${ }^{76}$ Although Birgivi does not explicitly discuss the matter of summary versus detailed faith in this text, in the section "On Knowledge" he states that the knowledge about what a given situation (i.e., 'ilm-i hă $l$ ) demands from one in terms of the law is obligatory for every individual ( fard al-ayn), while the knowledge of the sciences that allow one to reason about the underlying proofs of one's faith, and thus go beyond taqlìd, is obligatory for the community ( fard al-kifāya $).{ }^{77}$ Birgivī clearly endorsed the idea that seeking knowledge was the duty of each Muslim, as a popular hadith stipulated, but he apparently did not find it necessary or justified to raise the bar for being considered a true believer too high, especially in a text like Vașiyetnāme, which was written for the common folk, who did not know Arabic and lacked formal learning. Although he expressed the opinion that those who are capable of knowing but fail to do so are worse than animals, he was less concerned with the ignorance of the simple folk-which could be corrected through teaching - than with the arrogance and hypocrisy of the learned, which in his view pointed to serious moral failures and lack of piety. ${ }^{78}$

During his life, Birgivī attained prominence as a hadith teacher in a provincial hadith school in Birgi and authored numerous works in the tenor of moralist exhortation. Although he was well connected to the Ottoman establishment through his patrons, he did not belong to the highest ranks of the Ottoman ulama. But, his fame grew posthumously, and in recent years his catechetical works, especially his al-Tarīqa al-Muhammadiyya, have come under close scrutiny because he became an inspiration for various "puritan," "sunna-minded"79 preachers in the eleventh/seventeenth century, most notably for Ḳădī-

of this article, which is an expanded version of the paper he presented at the conference on "Re-thinking Ottoman Sunnitization, c. 1450-c. 1750" in Budapest, August 2017.

$7_{6}$ Birgivī, al-Tarīqah al-Muhammadīyah 18. I thank Sona Grigoryan for translating the relevant parts of the text.

77 Ibid. 23-24. See also Ivanyi, Virtue, piety and the law 183-184. The notion that ilm-i hâal encapsulates compulsory knowledge also appears in the Vașiyetnāme: "far $\dot{z}-i$ 'ayn olan 'ilimleri ki 'ilm-i ḥăldur." See Birgili, Vasiyyet-name 118.

78 This is particularly obvious in his discussion of unbelief (kufr) in al-Tariqa al-Muhammadiyya. On this issue see also Ivanyi, Virtue, piety and the law.

79 This term was suggested by Derin Terzioğlu in order to capture the variety of backgrounds and pious sensibilities displayed by various contemporary preachers who advocated for a reform based on firm rootedness in the Prophetic custom (sunna) and divine law (sharia), many of whom were Sufis. See Terzioğlu, Sunna-minded. For the most recent discussion on this issue, see Tuşalp Atiyas, The "Sunna-minded" trend. 
zāde Mehmed Efendi (d. 1045/1635) whose followers became known as the Kadızadelis. ${ }^{80}$ Nevertheless, on the subject of summary versus detailed faith he seems to have represented a more moderate Hanafi position compared to some of his contemporaries and later followers, including Kạdịizāde Meḥmed. In fact, it may even be said, in light of the discussion above about the late medieval creeds, that Birgivī was more faithful to the traditional Hanafi-Maturidi stance on these issues than İzniḳ̂, Aḳsarāyī, Lüțî Pasha, or later authors who are said to have been directly inspired by him.

Kâḍ̂izāde Meḥmed's own 'ilm-i ḥăl, for instance, exudes a spirit that is less "minimalist" when it comes to the issue of the importance of knowledge to faith. Under his penname (mahlaṣ) "ỉlmî," Kạdịizāde Meḥmed authored a popular versified catechism in 1037/1627-1628 in which he did not provide precise definitions of imañn-i icmālì or imān-i tafșilli, nor did he explicitly weigh in on whether the former or the latter is necessary. ${ }^{81}$ However, as a whole, the work is a vociferous endorsement of knowledge ( $\mathrm{i} / \mathrm{lm}$ ), which he not only adopts as his mahlas but which he repeatedly characterizes as the animating force of one's faith and piety. ${ }^{82} \mathrm{He}$ states that the essence of faith is to be found in the Quran and that it should be assented to in detail. ${ }^{83} \mathrm{He}$ envisions a process of learning in which professing belief in God's word epitomized by the Quran and assenting to it in one's heart is a starting point in a quest for a deeper, detailed understanding of the meaning of God's word. He also explicitly encourages moving beyond imitation toward verification. ${ }^{84}$ Above all, for Kạdịzāde Mehmed knowledge of faith is also essential for the cause that he presents as the reason for writing his 'ilm-i hăl, namely for the defense of the

8o Most important recent studies on Birgivī are Kaylı, A Critical Study and Ivanyi, Virtue, piety and the law. El-Rouayheb and Ivanyi see Birgivī as a representative of what they label as a "intolerant" or "illiberal" streak in the Hanafi-Maturidi tradition that possibly stems from postclassical, Central Asian Hanafism and is best epitomized by various postclassical fatwa compilations. See El-Rouayheb, From Ibn Ḥajar 303-304; Ivanyi, Virtue, piety and the law 82, 92.

81 By comparing the verses from Manzūme-i 'aḳ̂ảid and verses of Kạḍīzāde Mehmed Efendi cited by Kātib Çelebi in his Mizānül'-hakk, Songül Karaca demonstrates that the author of this versified catechism with the penname "İlmī" is the same Kāḍizāide Meḥmed Efendi. See Karaca, Kadızâde Mehmed Efendi 25-27. For further evidence, see Tezcan, The portrait.

82 Karaca, Kadızâde Mehmed Efendi 214. "Gel imdi ilm-ile kıl dînün ihyâ/ Ki cehl-ile ne dîn kalur ne takvâ."

83 Ibid. 205 .

84 "Hudâyâ eylegil fazlunla tevfîk/Geçür taklîdden kıl ehl-i tahkik." Interestingly, Karaca suggests that Kādīizāde borrowed these verses from the famous Sufi Celveti master Maḥmūd Hüdāyì (d. 1038/1628), 79-8o. 
true faith (that of ehl-i sünnet) against the heretics (ehl-i dalälet), whose ignorant views - especially under the guise of Sufism — are said to have proliferated in the author's time. ${ }^{85}$

As a more explicit contrast to Birgivī stands Aḥmed Rūmī Aḳhịịārī or Aḥmed Rūmī Efendi (d. c. 1041/1632), whose Risāle was an 'ilm-i hâal directly modeled on Birgivi's Vașiyetnāme and achieved great popularity, frequently being copied in miscellanies together with its model. Little is known of Aḳhịạārìs life apart from the fact that he was originally a Christian from Cyprus who was enslaved and later converted to Islam. ${ }^{86}$ Given the criticism of Ottoman authorities that he voiced in some of his works, he was apparently not courting dynastic patronage, and he seems to have spent most of his career in Akhisar in Anatolia, apparently without a formal position. ${ }^{87} \mathrm{He}$ authored a number of shorter treatises critical of what he perceived as harmful innovations in the spheres of belief, worship, and social life (especially tobacco and coffee). ${ }^{88}$ He may have read and used the work of Ibn Taymiyya (d. $728 / 1328$ ), and he was familiar with the work of the latter's student, Ibn al-Jawziyya (d. 750/1350), which has led scholars to band him together with Birgivi and the "Kadızadelis" as a representative of "Salafi Islam" who introduced Hanbali fundamentalism to Hanafism. ${ }^{89}$ However, the picture is more complicated, as Akhịisaarî’s reformist thought seems to have been informed by multiple influences. As Khaled el-Rouayheb has established, his treatise on taqlïd (Risäla fül-Taqlìd) consisted almost entirely of quotations from the fifteenth-century Maliki Ash'ari scholar al-Sanūsī and argued for the necessity of ascertaining the rational proofs for the articles of faithsomething that Hanbalis would not have agreed with. ${ }^{90}$ Plus, facile equations with other scholars blur the particularities of each author's intellectual outlook

\footnotetext{
85 "Zuhûr itdi nice bâtıl mezâhib/Bulup hakkı ana sen olma zâhib." Ibid. 240, 241-247.

86 See Michot, Introduction 1. See also Sheikh, Ottoman puritanism 41-45.

87 Tezcan, A canon of disenchantment.

88 For a list of his works, see Michot, Introduction 5-9.

89 Ibid. 2-3; Sheikh, Ottoman puritanism. For a reconsideration of that view, see Terzioğlu's paper in this volume.

9o El-Rouayheb, Islamic intellectual history 191. As El-Rouayheb points out, this stance on taqlìd in matters of imān was entirely opposed to the Hanbali stance on the issue. As for al-Sanūsī, his work is cited already by Ḥasan Kāfì Aḳhiṣārī (Pruščak) (d. 1024/1615) in his Rawḍat al-jannat fì ușūl al-i'tiqādāt (1014/1605), but it becomes more popular in the later eleventh/seventeenth century. Interestingly, in this work devoted to the nature of $\bar{i} m \bar{a} n$ and drawing on both Hanafi and Shafi'i, Maturidi, and Ash'ari creeds (including al-Sanūsì's and al-Suyūtī's), the author does not discuss the question of summary versus detailed faith, but he affirms the validity of the imitator's faith (with the remark that the latter is a sinner for neglecting to comprehend his faith). See Pruščak, Džennetske bašče 16.
} 
and particular context in which they wrote-even though he is known to have admired Birgivī, Aḥmed Rūmī Efendi was also ready to part with him on certain critical issues.

After he has discussed the positive and negative attributes of God in the beginning of his Risāle, Rūmī Efendi points out that knowing these attributes still does not suffice for one's faith to be sound. For that, it is necessary to know more about the articles of faith. It is not enough to simply say the shahäda, but one must also know of God's oneness and of the Prophet in greater detail; otherwise, one might learn wrongly and consider oneself a Muslim, but without learning about what makes imañn sound, one will reap none of its benefits. Indeed, one will be treated as a Muslim and spared from the poll tax, but in the afterlife a faith like this will earn one a place in Hell. ${ }^{91}$ Rūmì Efendi goes on to enumerate the six articles of faith, elaborating on each. Afterwards, he emphasizes that these articles should be learned in their entirety and memorized well (tamām ögrenüp hāțtralarında perkişdüreler), rather than relying on what one has learned from one's parents and grandparents, which may be wrong and may not lead to salvation in the afterlife. He emphasizes the importance of the knowledgeable ones within the ehl-i sünnet ve'l-cemáat teaching those who are ignorant to preserve them from küfr. Because, those who do not perform their worship and even commit some sins may still be allowed into Paradise after expiating their sins. But those ignorant ones who do not know God's attributes and what imān and Islam are, or who learn it wrongly, will end up in Hell eternally, even if they performed their worship day and night. ${ }^{92}$

It is no surprise, after this exposition on ìmān, that Rūmī Efendi comes down on the opposite side of Birgivì on the issue of whether or not imān-i icmāli is sufficient. He points out that whoever learns the articles of faith he elaborated on, believes in them in their heart, and professes them orally, has a detailed faith (imān-i tafṣillī). If, on the other hand, someone does not know all this and simply says "I believe that everything that Muhammad brought from God is true," this is imann-i icmālì. In truth, he says, scholars have considered this sufficient, but—and here he makes the same nod as Aksarāyī and Lüțî̀ Pasha to the legal stipulations on küfr, but without referring to any concrete fatwas- those who do not know the details of Islam when being asked about it and respond with "I do not know," become unbelievers (käfir olur). Therefore, there is no other solution than for one to learn what is necessary and keep refreshing it in order to be saved from eternal torments. ${ }^{93}$ The theme of being questioned

91 Aḳhị̦ārī, Risāle-i Rūmī Efendi 87b-88b.

92 Ibid. 93b-94b.

93 Ibid. 95a. 
about faith, which was mentioned in the context of Aksarāyīs and Lüțî Pasha's works, also pervades Rūmī Efendi's Risāle. Besides using it to justify the detailed knowledge of faith, he also warns newly married men to question their wives about faith on their wedding night, before consummating the marriage, but in such a way that the wife is not likely to say "I do not know" because that would necessitate annulment of the marriage. ${ }^{94}$ In the interest of brevity, Rūmì Ahmed states that he would not include a detailed discussion of elfäz-i i kürr, but he familiarizes his audience with the staple decision stipulated in the fatwa literature in the case of uttering blasphemous words (i.e., tecdīd-i ìmān ve nikāh, or renewal of faith and marriage vow).

The themes of having to know one's faith in detail from sound sources rather than unquestioningly accepting the word of one's parents or grandparents, being ready for being questioned about it, and guarding oneself from the utterances and actions that may lead to küfr is most forcefully brought home in an extraordinarily colorful catechetical work entitled Mebhas -i imān. It was written by Muṣlị̣u'd-dīn Mușțafā b. Ḥamza b. İbrahīm b. Veliyu'd-dīn, who went by the penname of Nuṣhị al-Nāṣı̣ì. He was a low-ranking member of the ulama and a Sufi, affiliated with the Naqshbandi brotherhood, who originally came from Bolu but who lived for many years in Cairo. ${ }^{95}$ In her discussion of this work, Derin Terzioğlu has already highlighted the extent to which Nuṣhì viewed the knowledge of ilm-i hă as the antidote to all sorts of social problems and troublesome innovations he perceived in the Ottoman polity of his own time. However, there is merit in taking a closer look at Nuṣhi's views on the issues of general, detailed, and imitative faith, since his work ties together the themes and authors discussed in the paper so far in a manner that helps us better appreciate the evolution of a particular strand of Ottoman Sunni understanding of $\bar{i} m \bar{a} n$. Writing around ${ }^{16} 33^{-1636}$, Nuṣhī already had a considerable corpus of catechetical literature in Turkish to consult for his synthesis of necessary knowledge about faith that he set out to present in his work. He informs his readers that he consulted 40 books, most of which he lists by title. Among the titles in Turkish, we find Birgivì's Vașiyetnāme, Ahmed Rūmì's Risāle, Shaykh Bālī el-Üveysī's Hediyetü'l-Muhliṣinn, ${ }^{96}$ Süleymān b. Halīl 'Unkūdī's Behcetü'l'ärifin ve ravżatü's-sālikin, and the Turkish translation of Shir'at al-Islām, a popular work by Muhammad b. Abū Bakr al-Bukhārī, known as Imāmzāda

$94 \quad$ Ibid. 99a.

95 Terzioğlu, Where 'ilm-i hăal; on Nuṣhī al-Nāṣı̣hị’s identity, see Tezcan, A portrait 228; Terzioğlu, Bid'at, custom.

96 This text is often incorrectly ascribed to Veysī (d. 1037/1628) in library catalogues and studies on Veysī. 
(d. 573/1177). A longer list in Arabic includes the staples of Hanafi creedal literature, such as Figh al-akbar and Wașiyya, attributed to Abū Ḥanīfa, and unspecified commentaries on both, Nasafís 'Aqā̉id as well as Taftāzānì's commentary on it and various supercommentaries on the latter, al-Ūshī's Bad' al-amālì (also known as Yaqūlal-'Abd) and three commentaries on it, as well as a text Nuṣhị refers to as 'Umdat, which is most probably Abū l-Barakāt al-Nasafi's 'Umdat al-'aqìda li-ahl al-sunna mentioned earlier. Interestingly, Nuṣhī also appears to have used Lüții Pasha's compendious catechetical work in Arabic entitled Zubdat al-masāill. Additionally, he also lists several works on figh, like Akmal al-Dīn al-Bābartīs (d. 786/1384-1385) sharh on Hidāya, and several works on kalām, such as Hediyetü'l-mehdiȳ̄n (or muhtedīn) by Ahīzāde Yūsuf Çelebi (d. c. 904/1499) and Bahrr al-kalām by Abū l-Mu'īn al-Nasafì (d. 508/1114). ${ }^{97}$ Among the last ones, he also lists al-Ghazālī's Ihyyà', which is nevertheless an important model for the author, at least in his division (if not precise content) of knowledge into that which is compulsory on each believer (fariz 'ı 'ayn) and that which is incumbent upon the community as a whole (fariz-ı kifäye).

In light of this list, which is heavily skewed toward classical Hanafi creedal and legal literature, more so than the source lists of other Ottoman authors discussed so far, it is interesting to examine how Nuṣhī handles the issues of imitative, general, and detailed faith. He opens his discussion on imañ by saying that a true believer's faith can be of three kinds: mukalled (imitated), muhakkak (certain, verified), and müstedel (deduced, inferred). He proceeds to state that in "our mezheb" (Ar. madhhab) - that of ehl-i sünnet ve'l-cemá'at (i.e., the Sunnis) —imitative faith is considered sound. ${ }^{98}$ However, because of rejecting reasoning, an imitator is a fäsı (impious, sinner; in breach of law). They call him imitator because he learned the faith wrongly from his parents or someone else, and his potential for being seduced by the devil is great. So, even though he admits that his own madhhab finds imitative faith acceptable, every time Nuṣhī mentions imitators and their faith, he implies that such faith must be riddled with mistakes and misunderstandings, and thus wrong. This is a remarkable contrast with the discussion in pre-Ottoman Hanafi creedal literature, all of which makes sure to point out that the mukallid's faith may lead to certainty in belief and that such a believer may have sound faith, while

97 Nuṣhī, Mebhas -i ìmān 61a-b. I thank Derin Terzioğlu for making her copy of the text available to me. It should be mentioned that various manuscripts of this work, including the one used here, attribute it to Kāạīzāde Meḥmed. However, by cross-referencing Nuṣhị’s works, Terzioğlu has demonstrated that this is not correct.

98 See below for a more detailed consideration of the usage of the term madhhab in Ottoman ilm-i hạls. 
only some authors bother to mention that if an imitator neglects to seek further information about faith they are to be considered sinners. Nuṣhì's position, however, is that such faith is by default wrong and sinful. He goes on to contrast it to the knowledge of those who learn their articles of faith from the books and the ulama, and who, if they have no doubts in their hearts, attain imman-i tahki $\bar{k} \bar{\imath}$ or verified faith. Finally, those who seek to understand the intricacies of every proof of God's existence have deduced faith, but he adds that such faith is only for the ulama and not of use for the common people for whom he is writing.99

As for the common people, they must prioritize their 'ilm-i ha $\bar{a} l$, which is knowledge about faith compulsory upon each believer. He states that the essence of faith (așl-i imān $)$ is comprised of six articles, while there are five pillars of Islam, both sets of which he discusses in detail. Further in the text, he includes a section that is almost verbatim from Ahmed Rūmì's Risāle and emphasizes the fact that imann consists of a number of things and that simply saying shahäda would not do. He reminds his audience that while shahāda (as ìmān-i icmālī) may be sufficient to be considered a Muslim, if one does not know the details about imān and Islam when asked, one becomes a käfir, and Hell is waiting for them in the afterlife, so it is essential for one's salvation to have detailed faith. ${ }^{100}$

The knowledge of these foundations of $\bar{i} m \bar{a} n$ and Islam, as he emphasizes, is not simply a vehicle for salvation and guarantee for entering Paradise; it also has a practical social application, of stemming what Nuṣhị perceives as an inexorable decline of Ottoman society starting around 950/1543-1544 due to neglect of the obligatory, farż $\iota$ 'ayn knowledge and favoring of the far $\dot{z}-\iota$ kifaye learning. In particular, anyone with a solid knowledge of 'ilm-i hă $l$ would be able, after just a short conversation, to identify heretics who have proliferated within the Ottoman realm and infiltrated the army and the government, according to Nuṣhī. Building on his passionate case for inculcation of the common believers in the basics of faith by the knowledgeable members of the community, neighborhood imams, and heads of households, Nuṣhī goes as far as to suggest an annual examination of all Muslim boys above the age of seven in their knowledge of 'ilm-i hăl, recommending expulsion from the neighborhood of those displaying ignorance or failure to learn. ${ }^{101}$

Like other authors of Ottoman 'ilm-i hạals, Nuṣhì pairs his insistence on the knowledge of the ilm-i ha $\bar{a} l$ with insistence on awareness of the boundaries

99 Nuṣhīi, Mebhas -i ìmān 62a-b. Also, later in the text, 108b-109a.

100 Ibid. 92a-95a.

101 Ibid. $74 a-75$ b. 
of $\bar{m} \bar{a} \bar{n}$ and necessity of guarding oneself from what is prohibited and corrupts one's faith. He argues that such awareness can be effectively attained by learning the examples of elfäz and ef'äl-i küfr (blasphemous acts), which Nuṣhī catalogues in great detail at the end of his work, providing a list of the fatwa collections that he consulted in order to compile this section. Again displaying a remarkable awareness of the moment and place in which he is writing, Nuṣhì anticipates Guy Burak's argument articulated in his study on the origins of the legal solution of tecdidd-i imān for cases of küfr, which highlights differences in the practices of Rumi and Arab Hanafis (see above). Along the same lines, Nuṣhì explains that he gave a detailed list of sources for this section, lest someone who lives in other parts of Ottoman or Muslim realms and does not have access to these fatwa compilations might think he is inventing things. Because, he continues, these fatwa compilations cannot be found in some regions (vilāyetler), and people do not know of the words that induce küfr. Some assert that Abū Haniffa had said that one should not accuse of küfr (i.e., engage in takfir) anyone who belongs to the people who pray toward Mecca (ehl-i kıble). However, in the Hanafi madhhab a person who pronounces elfäz-i küfr or does ef'äl-iküfr can become a käfir, but some who hear of this reject that this is a Hanafi tradition. For instance, it is reported that the ulama of Egypt have not been giving fatāw $\bar{a}$ on küfr for anyone who pronounces elfäz-i küfr, but this is either because they are afraid of people and try to flatter them, or they are ignorant of these things. There is no local transmission of this kind of fatāwa , and without tradition or precedent (haml) a juridical opinion cannot be given. ${ }^{102}$

The latter explanation is important because it highlights the diversity within the Hanafi madhhab across the Ottoman Empire. Even in the context of the lands of Rum, it would be wrong to suggest that by the eleventh/seventeenth century all Ottoman 'ilm-i hăl writers made an 180 degree turn from the earlier Hanafi-Maturidi position; rather, a variety of positions coexisted, although with a marked tendency toward the stance that imann-i tafșill is necessary for salvation. ${ }^{103}$ As we have seen, the debate on this issue was complicated by the

102 Ibid. 128a.

103 For instance, if we focus on the late eleventh/seventeenth century, Ebū'l-Bekā el-Kefevī (d. 1095/1684) in his popular 'ilm-i hâal entitled Tühfetü'ş-şahān, which in its 'aḳāid section draws significantly and often verbatim on Birgivī's Vașiyetnāme, did not strive to close the apparent logical gap between the idea that summary faith is sufficient to be considered a true believer, as stated by Birgivī, and the provision, which Kefevī also refers to, that failure to answer the question "what is faith?" in detail makes one an unbeliever and requires a renewal of faith and marriage vow. See the transcription of the 'akâ'id section of Kefevìs work in Tarı, Ebü'l-Bekâ el-Kefevî 591-6o6, esp. 6o2. In contrast, an anonymous volumi- 
fact that various authors appear to have understood differently what "summary" and "detailed" meant as qualifiers of faith. For instance, in his popular work on creed entitled Dürerü'l-'akẩid, written some time before 1024/1615, the famous Halveti Sufi shaykh and preacher 'Abdü'l-mecīd Sivāsī (d. 1049/1639) mounts a vocal defense of both summary/general faith and the faith of an imitator, stating that both are accepted by the consensus of the Sunni community and that an imitator, even though he may be a rebel for not understanding the proofs, is still a believer as long as he has no doubts in faith. ${ }^{104}$ However, Sivāsì's definitions are interesting: he underlines that ìmān-i icmā $\bar{l}$ means having faith in general terms, such as saying that one believes in angels, and books, and prophets. Imān-i tafșilli, on the other hand, denotes detailed belief that can distinguish between the angels by name, like Cibrā̄ill and Mihā̄ill, and the prophets, like Mūsā and 'Īsā, and the books, like Tevrāt and İncīl. Sivāsī emphasizes that while professing faith in general is sufficient $(k \bar{a} f \hat{\imath})$, detailed faith is a necessary condition (şart ), because anyone who does not believe in or outright denies the singularity or multiplicity contained in a particular category of belief is a käfir. ${ }^{105}$ In light of the previous discussion, it appears that Sivāsī assumes a more detailed knowledge under the category of general faith than most Hanafi authors.

Sivāsi's treatment of the topic raises the question of whether we may perhaps trace a dissenting streak in 'ilm-i hă prominent Sufis, a streak that pushes back against the narrowing definitions of belief and greater demands on the believer typically associated with the followers of Kăạīzāde Meḥmed Efendi-who famously clashed with Sivāsī in the late 1620 s and 1630 - and various other eleventh/seventeenth-century sunna-minded commentators. ${ }^{106}$ While a detailed consideration of this question requires a separate study, a limited inquiry into the contents of some popular eleventh/seventeenth-century Sufi works suggests that this was not the case. It appears that even those authors who did not explicitly embrace the necessity of having imān-i tafșill found it important to signal its superiority over ìmāni i icmālè in no uncertain terms. For instance, Münīrīi Belgrādī (d. 1045/1635), a well-known Rumeli Sufi who authored an 'ilm-i hạl entitled Sübülüll-Hüdā, opens his work with a discussion of $\bar{i} m \bar{a} n$, stating that faith can be general and

nous 'ilm-i hăl work written around 1099/1688 that draws on a variety of medieval and Ottoman-era creedal works, stipulates (without any reference to summary faith) that the detailed faith is obligatory (vâcibdür). See Atar (ed.), Makâlât 61.

104 Sivāsī, Dürerü'l-'aḳāid, 17b-18a.

105 Ibid. 13a-b.

106 On the clash between the two Zilfi, The Kadizadelis; Çoban, Mihnet dönemi. 
detailed. He defines the former as professing belief that everything Muhammad brought from God is true and says that this is sufficient to make one a mümin and worthy of Paradise. However, he points out that whoever has detailed faith will earn a place in Paradise that is superior to that of someone with general faith. ${ }^{107}$ Another eleventh/seventeenth-century work on immann, an anonymous Risāle-i 'amāniye [sic] that is also likely authored by a Sufi, states that upon the consensus of the ulama, icmāli imañ entails affirmation that God is one, that Muhammad is his prophet, and that everything he brought from God is true. In principle, this knowledge is sufficient, but it is compulsory on each believer ( far ż-ı 'ayn) to learn the details of faith, as God has ordered that religion must be based on comprehension (tefakkuh) and prohibited ignorance. ${ }^{108}$

An intriguing illustration of the eleventh/seventeenth-century Sufi authors' tendency to emphasize the importance of greater knowledge for sound faith comes from the famous Halveti shaykh Niyāzī-i Mıșrī (d. 1105/1694), who discusses this issue in his widely popular Risāle-i Es'ile ve ecvibe. ${ }^{109}$ As Mıșrī states, he wrote this work in order to dispel the doubts about Sufis caused by some of the things they say, which are misinterpreted by the common people and some ulama - an age-old problem that Sufis had to deal with but that now gained new visibility and mobilized society in a new way. From the 163 os onward, Sufis had borne the brunt of the Kadızadelis' rants against the blameworthy innovations in belief and practice, as well as accusations of shunning the sharia. Mıșri's goal was to show that Sufis belong to the people of God and to the Sunni mezheb, and more precisely, when it comes to Sufis from the lands of Rum (Rüm vilāyeti), to the mezzhebs of Abū Manșūr al-Māturīdī and Abū Ḥanīfa. Mıșrì's introduction, similar to contemporary ilm-i hă als, highlights the broader usage of the term mezheb (Ar. madhhab, "that which is followed"; "the opinion one adopts") — which is typically used by modern scholars only to index belonging to one of the schools of Islamic law-to denote sectarian (or denominational) and theological affiliation as well. In the view of the Ottoman 'ilm-i hâal authors, there was only one correct mezheb in terms of belief ( $\bar{l} t i k \bar{a} d)$, and that was the Sunni mezheb. ${ }^{110}$ At the same time, although they professed affiliation with the

\footnotetext{
107 Belgrādī, Sübülü'l-hüdā 11a-b.

108 Risāle-i amāniye 55a.

109 On Mıșrī’s career and contemporary religio-political dynamics, see Terzioğlu, Sufi and dissident.

110 Thus, in the context of the Ottoman 'ilm-i häl literature, the madhhab of ahl al-sunna wal-jamā $\bar{a} a$ is conceptually equal to the al-firqa al-näjiyya in the heresiographical literature, the latter typically being understood as the only sect of Islam (out of 73) that guarantees salvation. Both the term madhhab and the term firqa are here imbued with claims to being exclusive repositories of "truth," and both are oriented externally, towards other groups.
} 
Hanafi and Maturidi mezzheb, respectively, and emphasized their primacy, in terms of legal practice and method of theological argumentation, they allowed for plurality and regarded these largely a matter of a Muslim's geographical provenance. ${ }^{111}$ Altogether, however, in this era of polarization both within the Sunni community and between Sunnis and Shi'ites, 'ilm-i hâal authors accorded considerable attention to an ever-more precise identification and classification of Ottoman Muslims, and Mıșrī felt obliged to provide his brethren's "coordinates" on this map, rooting them firmly in the categories of Sunni, Hanafi and Maturidi, endorsed by the Ottoman religious establishment.

The opening question of the risāle is: what is the basis of Sufism? Mıșrī responds that it is faith ( $\bar{\imath} m \bar{a} n$ ), which has six pillars-belief in God's existence and unity, his angels, prophets, books, the Day of Judgment, and that both good and bad is owing to God. The second question seeks to know the difference between the common people ('avām) and Sufis, to which he responds that the difference is that 'avām's faith in these six articles of faith is imitative (taklīi $\bar{l}$ ) while the Sufis' is verified (tahkīki $)$ and the ulama's is reasoned (istid$l \bar{a} l \bar{\imath})$. He continues to explain that imitative faith is based on authority of others but without understanding the underlying proofs, which resembles finding a precious stone but not knowing its value. Verified faith, on the other hand, is one that seeks to arrive at the truth of every article of faith. He states that the road between the "village of imitation" (taklìd köyü) and "city of verification" (tahkik s şehri) is the Sufi path ( ilm-i tarikat), and that ultimately, the difference between the common people ('avām and havās) and Sufis is in the degrees of wisdom/knowledge (merātib-i ma'rifet). ${ }^{112}$

Mıșri's explanation helps us understand the difference between the Sufi concept of verification of faith (associated with a journey on the mystical path toward the Truth) and the more kaläm-informed notions featured in the texts

The precise meaning of these terms when translated into English is a matter of debate among Islamicists (both are frequently translated as "sect," while madhhab is also sometimes rendered as "denomination"), but it is safe to say that their precise connotations vary depending on historical context, genre, and perspective of the author. For a recent debate on the vocabulary of sectarianism in Islam, that nevertheless does not consider Ottoman context in detail, see Sedgwick, Sects in the Islamic world.

111 The point is most clearly driven home by Birgivī who in his Vașiyetnāme states that in terms of belief (itikâd) "we" are the followers of the only true and correct mezhep, that of the ehl-i sünnet ve'l cemā'at, while in terms of practice ('amel), we are the followers of the mezheb of Abū Hanīfa, which is preferred, but others may be correct as well. The same point is elaborated in detail by Kạḍīzāde Meḥmed Efendi in his versified 'ilm-i hạal. See Karaca, Kadızâde Mehmed Efendi 226-229.

112 Mıșrī, Risāle-i Es'ile ve ecvibe. I consulted two manuscripts of this popular work: İ.B.B. Atatürk Kitapliği, Bel Yz Ko267, 36a-43a and Bel Yz Ko5o2, 64a-70a. 
discussed above. Despite these differences, however, his work highlights the shared importance of knowledge and rejection of imitation in faith in the era when various Muslims' claims to have verifiable access to the divine message came under greater scrutiny. As suggested above, by Mısrri's time the opinion of the Ottoman catechists and the larger moral community, at least in the lands of Rum, by and large moved toward a higher threshold for sound faith than what was envisioned by medieval Hanafi-Maturidis, putting more emphasis on detailed knowledge, importance of reasoning, dangers of imitation, and significance of verification. The fact that he wrote this short treatise for a popular audience in order to defend fellow Sufis from accusations of unbelief and that he formulated his defense in terms of imitation and verification, suggests that these were also the norms vis-à-vis which Sufis, as others, had to position themselves and to which they were supposed to conform, at least in the public eye, in the era of intensified debates on the nature and boundaries of Sunni Islam.

Conclusion: Imān and Küfr in the Age of Building a Sunni Madhhab Consciousness

In a recent article, Lutz Berger remarked that in contrast to classical theology, which was born in part as an answer to political and social issues that emerged in the early Islamic era, there was little that kaläm could offer to address the social and political problems that the Mamluks and Ottomans were facing. In trying to explain why, despite this, Mamluks and Ottomans opted to largely preserve the paradigm of classical theology, Berger dismisses the idea that the study of kaläm was deemed useful because it helped scholars debate non-Muslims or heresy within Islam and suggests that its function was largely sociological, since education in theology was part and parcel of the scholars' academic credentials and, by extension, their social status. ${ }^{113}$ While it is certainly true that kaläm continued to be a staple of the Ottoman scholars' education, as this paper as well as other articles in this volume (especially Nabil Al-Tikriti's and Nir Shafir's) demonstrate, theology had a broader social significance that was directly connected to the realities of a confessionally polarized Islamic and wider early modern world that made a detailed knowledge of one's faith a new imperative in the face of proliferating — but false, it is impliedalternative paths to the salvation.

113 Berger, The interpretation $700-701$. 
At the same time, as Khaled El-Rouayheb has convincingly argued, we need to revise the view that while theology in the medieval - and early modern, I would add-Christian context served to deepen faith in the mysteries of the creed and fortify the believers' understanding of their faith, kaläm was an apologetic and defensive discipline that merely served to defend the creed against heretics and infidels. ${ }^{114}$ Through his detailed study of al-Sanūsì's work, El-Rouayheb showed that al-Sanūsī understood kalām as a demonstrative not dialectical science, and viewed mastery of its essentials as a religious duty incumbent on each adult Muslim. While Ottoman Hanafi catechists did not go as far as al-Sanūsì to reject the simple, unreasoned faith of the commoner, most of them were sympathetic to the emphasis on the necessity of a more detailed knowledge and more thorough instruction in proofs of God's oneness and of each article of faith, making this aspect of classical kaläm incumbent upon each believer.

In developing this position, Ottoman authors appear to have drawn both on a particular strand in the postclassical eastern Hanafism, which they have elevated to a state-endorsed orthopraxy, and on the synthesis of Maturidi and Ash'ari theological views that began already in the eighth/fourteenth and ninth/fifteenth centuries and may have induced Ottoman authors to be more open to the arguments that a detailed knowledge of faith is a prerequisite for salvation. However, we see that it is really in the mid-tenth/sixteenth and especially in the eleventh/seventeenth century when this perspective is more openly embraced and when the thought of Ash'ari theologians with an antitaqlìd bent becomes a welcome intellectual resource to tackle the social issues of the day. It is in this period that the debate about the nature, content, and boundaries of Sunnism peaked, especially in the Ottoman lands of Rum, but also between Rumi and Arab literati of both shared and different legal madhhab allegiances. ${ }^{115}$

The notions of being questioned about one's faith and the consequences of not knowing the correct answers-namely, the possibility of plunging into unbelief-strongly inform those Ottoman catechisms that insist on a detailed knowledge of faith. In a recent essay examining what might be the essence of the phenomenon of "confessionalization" in a comparative early modern perspective, Cornel A. Zwierlein has suggested that confessionalization was at its root an epistemic process of constantly asking questions about how the belief and practice in real life compared to the theological norms and expectations,

114 El-Rouayheb, Islamic intellectual history 173.

115 On this see Shafir, The road from Damascus, esp. 87-164. 
seeking to correct the deviations. ${ }^{116}$ It would appear that the Ottoman catechisms in question display the same impulse to correct and verify and envision the same role for theology as in a contemporary Christian context, not only as a tool for protecting the faith from external attacks but also as a means of deepening one's understanding of its precepts. While the intellectual resources and inspiration for the reconsideration of the boundaries of faith and the centrality of knowledge in these Ottoman catechisms came from within the Islamic tradition, they helped their authors tackle the challenges that seem to have been shared by theologians across confessional and geographic borders of the early modern world. Although not all Ottoman catechisms were equally insistent on possessing a detailed knowledge of one's faith, and there were many Muslims who resisted the idea that the boundaries of Sunni Islam can and should be narrowly defined, these texts demonstrate that we cannot anymore argue that Ottoman "Sunnitization" or the process of defining and enforcing a particular definition of Sunnism was a purely political project that was content with occasionally persecuting Shi'ites and forcing Ottoman Sunnis to pray more regularly without any novel theological basis or genuine intension to correct their faith.

\section{Acknowledgments}

I would like to thank the anonymous reviewer as well as Derin Terzioğlu, Sona Grigoryan, Günhan Börekçi, Guy Burak, Sait Özervarlı, Ulrich Rudolph, and Aziz al-Azmeh for their insightful comments and suggestions while writing this article. Research for this essay was supported by the European Research Council (ERC) Consolidator Grant under the European Union's Horizon 2020 research and innovation program (grant agreement No 648498).

\section{Bibliography}

\section{Primary Sources (Published and Unpublished)}

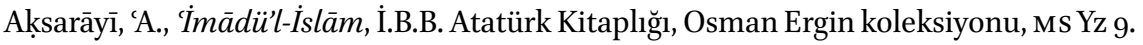
Aḳ̣ị̦ārī, A.R., Risāle-i Rūmī Efendi, Universitätsbibliothek Leipzig, Ms B. or 177/2. Atar, R. (ed.), Makâlât: İlmihâl, Istanbul 2017.

Belgrādī, M. Sübülüll-hüdā, Biblioteca Universitaria Bologna, Ms 3445, 9b-59b.

116 Zwierlein, "Konfessionalisierung." 
Birgili, M., Vasiyyet-name: Dil incelemesi, metin, sözlük, ekler indeksi ve tıpkıbasım, ed. M. Duman, Istanbul 2000.

Birgivī, Mehmed Efendi. al-Ṭarīqah al-Muhammadīyah wa-al-sīrah al-Aḥmadīyah, Istanbul 1898.

Cürcâni, Şerhu'l-Mevâkıf, 2 vols., trans. Ö. Türker, İstanbul 2015.

al-Ghazzālī, The foundations of the articles on faith: Translation with notes of Kitāb Qawā'id al-'Aqā’id of Al-Ghazzālı̀'s Ihyā' 'Ulūm al-Dīn, trans. N.A. Faris, Beirut 1963.

Karaca, S., Kadızâde Mehmed Efendi, Manzûme-i akâid (inceleme-tenkitli metinsözlük-dizin), MA thesis, Recep Tayyip Erdoğan Üniversitesi, Rize 2012.

Kutbe'd-dîn İznikî, Mukaddime: Giriş-İnceleme-Metin-Sözlük, ed. K. Üstünova, Bursa 2003.

Lüț̣ī Pasha, Tenbihhül-‘ạkılīn ve te’kìdül-gāfilinn, Millet Kütüphanesi, Ms Ali Emiri Şer'iyye $257,1 a-52 b$.

Mıșrī, N., Risāle-i Es'ile ve ecvibe, İ.B.B. Atatürk Kitaplı̆̆̆, Ms Bel Yz Ko267, 36a-43a.

Mıșrī, N., Risale-i Es'ile ve ecvibe, İ.B.B. Atatürk Kitaplı̆̆ı, Ms Bel Yz Ko5O2, 64a-70a.

al-Nasafî, A.B., 'Umdat al-'aqìda li-ahl al-sunna, in W. Cureton (ed.), Pillar of the Creed of the Sunnites, London 1843, 1-29.

en-Nesefî, E.B, Islâm inancının ana umdeleri ("el-Umde” Tercümesi), trans. T. Yeşilyurt, Malatya, 2000 .

Nuṣḥ̄ al-Nāṣıı̣̄i, Mebḥaś-i ìmān, Süleymaniye Kütüphanesi, Ms Yazma bağışlar 5563, $59 \mathrm{~b}-136 \mathrm{~b}$.

Pezdevî, Ehl-i sünnet akâidi, trans. Ş. Gölcük, Istanbul 2017.

Pruščak, H.K., Džennetske bašče o temeljima verovanja (Rawdat al-jannat fi usul ali'tiqadat), trans. M. Handžić, Sarajevo 2000.

Risāle-i 'amāniye, Biblioteca Apostolica Vaticana, ms Borg. Turc 5, 55a-68b.

es-Sâbûnî, N., Mâtürîdiyye akaidi, trans. B. Topaloğlu, Istanbul 2011.

es-Semerkandî, E.M.R.U., el-'Akîdetü'r-rükniyye fî şerhi lâ ilâhe illallah Muhammedün

Resûlullah, ed. M. Sinanoğlu, Istanbul 2008.

Sivāsī, 'A., Dürerü'l- 'aḳ̂̄id, Süleymaniye Kütüphanesi, ms Mihrişah 300.

al-Taftāzānī, S., A commentary on the creed of Islam: Sa'd al-Dīn al-Taftāzānī on the creed of Najm al-Dìn al-Nasafi, ed. and trans. E.E. Elder, New York 195 o.

al-Ūshī, Bad' al-amāli, trans. A. Hasan, Ridawi Press 2017.

Yazıcıŏ̆lu, M., Muhammediye, 2 vols., ed. A. Çelebioğlu, Istanbul 1996.

\section{Secondary Sources}

Ahmed, S., What is Islam?: The importance of being Islamic, Princeton 2016.

Ahmed, A.Q., Post-classical philosophical commentaries/glosses: Innovation in the margins, in Oriens 41 (2013), 317-348.

Atçl, A., Scholars and sultans in the early modern Ottoman Empire. Cambridge, New York 2017. 
Aynacı, M., Osmanlı kuruluș dönemi Türkçe ilmihal eserleri çerçevesinde ilmihallerin fikhî yönden değerlendirilmesi, PhD diss., Marmara Üniversitesi 2009.

Bake, M.R., Ubeydallah b. Muhammed b. Abdulaziz es-Semerkandî’nin ulûhiyet görüşü, MA thesis, İstanbul Üniversitesi 2005.

Badeen, E., Sunnitische Theologie in osmanischer Zeit, Würzburg 2008.

Berger, L., The interpretation of Ash'arism and Maturidism in Mamluk and Ottoman times, in S. Schmidtke (ed.), The Oxford handbook of Islamic theology, Oxford, New York 2016, 693-706.

Burak, G., Faith, law and empire in the Ottoman "age of confessionalization" (fifteenthseventeenth centuries): the case of "renewal of faith," in Mediterranean historical review 28 (2013), 1-23.

Burak, B., The second formation of Islamic law: The Hanafi legal school in the Ottoman Empire, Cambridge, New York 2015.

Calder, N., The limits of Islamic orthodoxy, in A. Rippin (ed.), Definining Islam: A reader, New York 2014, 222-236. [Originally published in Intellectual traditions in Islam, F. Daftary (ed.), London 200o, 66-86.]

Çoban, A., Mihnet dönemi sufiliğinde savunma amaçlı akaid yazıcılığı: XVII. yüzyıl Osmanlı'sında iki sufi iki eser, in Tasavvuf 26 (2015), 1-30.

Daiber, H., The Islamic concept of belief in the 4th/roth century, Tokyo 1995.

Demir, O., V. Kaya, K. Gömbeyaz and U.M. Kılavuz (eds.), Osmanlida ilm-i kelâm: Âlimler, eserler, meseleler, Istanbul 2016.

Eichner, H., Handbooks in the tradition of later Eastern Ash'arism, in S. Schmidtke (ed.), The Oxford handbook of Islamic theology, Oxford, New York 2016, 494-514.

Endress, G., Reading Avicenna in the madrasa: Intellectual genealogies and chains of transmission of philosophy and the sciences in the Islamic East, in J.E. Montgomery (ed.), Arabic theology. Arabic philosophy: From many to the one: Essays in celebration of Richard M. Frank, Leuven, Paris, Dudley, 2006, 371-422.

Fitzgerald, T.J., Murder in Aleppo: Ottoman conquest and the struggle for justice in the early sixteenth century, in JIS 27 (2016), 176-215.

Frank, R.M., Knowledge and taqlîd: The foundations of religious belief in classical Ash'arism, in JAOS 109 (1989), 37-62.

Hira, A., Bir katalog yanıltması: Kırk Emre Mehmed b. Mustafa el-Hamîdî el-Karamanî'nin (ö. 1475) Şeyh Bedreddin'e (ö. 1420) nispet edilen Câmiu'l-fetâvâ adli eseri, in Sosyal bilimleri enstitüsü dergisi 10 (2012), 67-89.

Izutsu, T., The concept of belief in Islamic theology: A semantic analysis of iman and Islam, Tokyo, Yokohama 1965.

Ivanyi, K.A., Virtue, piety and the law: A study of Birgivī Meḥmed Efendì's al-Tarīqa alMuhammediyya, PhD diss., Princeton University 2012.

Kartal, A., Kutbuddin b. Muhammed İzniki (?-821 H.) ve Râhat'ul-kulub (Mukaddimei Kutbuddîn) isimli eseri, in Şiraz'dan İstanbul'a: Türk Fars kültür coğrafyası üzerine araştırmalar, Istanbul 2010, 534-543. 
Kaylı, A., A critical study of Birgivi Mehmed Efendi's (d. 981/1573) works and their dissemination in manuscript form, MA thesis, Boğaziçi University 2010.

Kelpetin Arpaguş, H., Bir telif türü olarak ilmihal tarihî geçmişi ve fonksiyonu, in Marmara Üniversitesi ilâhiyat fakültesi dergisi 22 (2002-2001), 25-56.

Kelpetin Arpaguş, H., İmâdü'l-İslâm, in TDViA, xxii, 172-173.

Kelpetin Arpagus,, H., İlk ilmihal örneklerinden Imâdül-İslam, in Osmanlıve geleneksel İslâm, İstanbul 2014, 65-109.

Krstić, T., Contested conversions to Islam: Narratives of religious change in the early modern Ottoman Empire, Palo Alto 2011.

Krstić, T., A catechizing grand vizier: Lüțī Pasha (d. 1563) and the politics of Sunni confession- building in the sixteenth-century Ottoman Empire, in R. Gradeva (ed.), Agents of faith in the Ottoman Balkans, forthcoming.

Krstić, T., From shahāda to 'aqìda: Conversion to Islam, catechization, and Sunnitization in sixteenth-century Ottoman Rumeli, in A.C.S. Peacock (ed.), Islamisation: Comparative perspectives from history, Edinburgh 2017, 296-314.

Krstić, T., State and religion, "Sunnitization" and "confessionalism" in Süleyman's time, in P. Fodor (ed.), The battle for Central Europe: The siege of Szigetvár and the death of Süleyman the Magnificent and Nicholas Zrínyi (1566), Leiden, Boston, Budapest 2019, 65-92.

Madelung, W., The early Murji’a in Khurāsān and Transoxania and the spread of Hanafism, in Der Islam 59 (1982), 32-39.

Melvin-Khoushki, M., Tahqīq vs. taqlìd in the renaissances of western early modernity, in Philological encounters 3 (2018), 193-249.

Meshal, R.A., Sharia and the making of the Modern Egyptian: Islamic law and custom in the courts of Ottoman Cairo, Cairo, New York 2014.

Michot, Y., Introduction, in A. al-Aqhịisāīī, Against smoking: An Ottoman manifesto, ed. and trans. Y. Michot, Leicestershire 2010.

Mohamed, Y., The Path to virtue: The ethical philosophy of al-Rāghib al-Ișfahānī, Kuala Lumpur 2006.

Mohamed, Y., The ethics of education: al-Iṣfahānī's $a$-Dharī ' $a$ as a source of inspiration for al-Ghazālì's Mìzān al-'Amal, in $M W 101$ (2011), 633-657.

Ökten, E., Why ordinary utterances turn into problems of faith? (forthcoming)

Öngören, R., Kutbüddin İznikî, TDVİA, xxvi, 485-486.

Özervarl, M.S., Theology in the Ottoman lands, in S. Schmidtke (ed.), The Oxford handbook of Islamic theology, Oxford, New York 2016, 567-586.

Pourjavady, R., Philosophy in early Safavid Iran, Leiden, Boston 2011.

Rabb, I.A., Society and propriety: The cultural construction of defemation and blasphemy as crimes in Islamic law, in C. Adang, H. Ansari, M. Fierro and S. Schmidtke (eds.), Accusations of unbelief in Islam, Leiden, Boston 2016, 434-464.

El-Rouayheb, K., Islamic intellectual history in the seventeenth century: Scholarly currents in the Ottoman Empire and the Maghreb, Cambridge, New York 2015. 
El-Rouayheb, From Ibn Ḥajar al-Haytamī (d. 1566) to Khayr al-Dīn al-Alūsī (d. 1899): Changing views of Ibn Taymiyya among non-Hanbalī Sunni scholars, in Y. Rapoport and S. Ahmed (eds.), Ibn Taymiyya and his times, Karachi 2010, 269-318.

Rudolph, U., Al-Ghazālī on philosophy and jurisprudence, in P. Adamson (ed.), Philosophy and jurisprudence in the Islamic world, Berlin, Boston 2019, 67-92.

Rudolph, U., Al-Māturìdī and the development of Sunni theology in Samarqand, trans. R. Adem, Leiden, Boston 2015.

Rudolph, U., Ratio und Überlieferung in der Erkenntnislehre as-Aš‘arìs und al-Māturīdì's, in ZDMG 142 (1992), 72-89.

Saleh, W.A., The gloss as intellectual history: The hạshiyahs on al-Kashshāf, in Oriens 41 (2013), 217-259.

Sedgwick, M., Sects in the Islamic world, in Nova religio: The journal of alternative and emergent religions 3 (2000), 195-240.

Shafir, N., The road from Damascus: Circulation and the redefinition of Islam in the Ottoman empire, 1620-1720, PhD diss., University of California, Los Angeles 2016.

Sheikh, M., Ottoman puritanism and its discontents: Aḥmad al-Rūmī al-Āqḥișārī and the Qādīzādelis, Oxford, New York 2016.

Spannaus, N., Theology in Central Asia, in S. Schmidtke (ed.), The Oxford handbook of Islamic theology, Oxford, New York 2016, 587-6o5.

Tarık, R., Ebü'l-Bekâ el-Kefevînin Tuhfetüş-şahân'ında İslâm akâidi, in Mezhep araştırmaları dergisi 12 (2019), 572-6o9.

Terzioğlu, D., Bid'at, custom and the mutability of legal judgments: The debate on the congregational performance of supererogatory prayers in the seventeenth-century Ottoman Empire, in A. Somel and S. Kenan (eds.), Dimensions of transformation in the Ottoman world: Essays in honor of Metin Kunt, Leiden (forthcoming).

Terzioğlu, D., How to conceptualize Ottoman Sunnitization: A historiographical discussion, in Turcica 44 (2012-2013), 301-338.

Terzioğlu, T., Sufi and dissident in the Ottoman Empire: Niyāzī-i Mıșrī (1618-1694), PhD diss., Harvard University 1999.

Terzioğlu, T., Sunna-minded Sufi preachers in service of the Ottoman state: The Nașihatnāme of Hasan addressed to Murad IV, in Archivum Ottomanicum 27 (2010), 241-312.

Terzioğlu, T., Where 'ilm-i hă $a$ meets catechism: Islamic manuals of religious instruction in the Ottoman Empire in the age of confessionalization, in Past and present 220 (2013), 79-114.

Tezcan, B., The portrait of the preacher as a young man: Two autobiographical letters by Kadızade Mehmed from the early seventeenth century, in M. Sariyannis (ed.), Political thought and practice in the Ottoman Empire, Rethymno 2019, 187250.

Tezcan, B., A canon of disenchantment: Birgivi, Rumi, and Kadızade, in Baki Tezcan, $A$ 
gift for the Turks: Studies on Islam and its early modern transformation in the Ottoman Empire, Istanbul IsIS 2021 (forthcoming).

Al-Tikriti, N., Kalam in the service of the state: Apostasy and the defining of Ottoman Islamic identity, in H. Karateke and M. Reinkowski (eds.), Legitimizing the order: The Ottoman rhetoric of state power, Leiden, Boston 2005, 131-150.

Tuşalp Atiyas, E., The "Sunna-minded" trend, in M. Sariyannis, A history of the Ottoman political thought up to the nineteenth century, Leiden, Boston 2018, 233-278.

van Ess, J., Die Erkenntnislehre des 'Adudaddin al-İcī: Übersetzung und Kommentar des Ersten Buches seiner Mawāqif, Wiesbaden 1966.

van Ess, J., Theology and society in the second and third century of the Hijra, i, trans. J. O'Kane, Leiden, Boston 2017.

Watt, W.M., Islamic philosophy and theology, Edinburgh 1985.

Watt, W.M., Islamic creeds: A selection, Edinburgh, 1994.

Wensinck, A.J., The Muslim creed: Its genesis and historical development, New York 1932. Wiederhold, L., Blasphemy against the Prophet Muhammad and his companions (sabb al-rasūl, sabb al-ṣahāabah): The introduction of the topic into Shāfi'i legal literature and its relevance for legal practice under Mamluk rule, in Jss 42 (1997), 39-70.

Würtz, Th., Islamische Theologie im 14. Jahhundert: Auferstehungslehre, Handlungstheorie und Schöpfungsvorstellungen im Werkvon Sa'd ad-Din at-Taftazani, Berlin, Boston 2016.

Yazıcıoğlu, M.S., Le kalâm et son rôle dans la société turco-ottomane auXVe et XVIe siècles, Ankara 1990.

Zilfi, M., The Kadizadelis: Discordant revivalism in seventeenth-century Istanbul, in JNES 45 (1986), 251-269.

Zwierlein, C.A., 'Konfessionalisierung' europaisch, global als epistemischer Prozess. Zu den Folgen der Reformation und zur Methodendiskussion, in C. Strohm (ed.), Reformation und Recht, Tübingen 2017, 1-52. 